\title{
Optimized Bioconversion of Xylose Derived from Pre-Treated Crop Residues into Xylitol by Using Candida boidinii
}

\author{
Soma Bedő $^{1}$, Anikó Fehér ${ }^{1}$, Panwana Khunnonkwao ${ }^{2}$, Kaemwich Jantama ${ }^{2}$ and Csaba Fehér ${ }^{1, *(D)}$ \\ 1 Biorefinery Research Group, Department of Applied Biotechnology and Food Science, \\ Budapest University of Technology and Economics, 1111 Budapest, Hungary; bedo.soma@mail.bme.hu (S.B.); \\ feher.aniko@mail.bme.hu (A.F.) \\ 2 Metabolic Engineering Research Unit, School of Biotechnology, Institute of Agricultural Technology, \\ Suranaree University of Technology, 111 University Avenue, Suranaree Sub-District, Muang District, \\ Nakhon Ratchasima 30000, Thailand; panwana@outlook.com (P.K.); kaemwich@g.sut.ac.th (K.J.) \\ * Correspondence: feher.csaba@vbk.bme.hu
}

Citation: Bedő, S.; Fehér, A.;

Khunnonkwao, P.; Jantama, K.; Fehér, C. Optimized Bioconversion of

Xylose Derived from Pre-Treated Crop Residues into Xylitol by Using Candida boidinii. Agronomy 2021, 11,

79. https://doi.org/10.3390/ agronomy11010079

Received: 27 November 2020 Accepted: 29 December 2020 Published: 1 January 2021

Publisher's Note: MDPI stays neutral with regard to jurisdictional clai$\mathrm{ms}$ in published maps and institutional affiliations.

Copyright: (C) 2021 by the authors. Licensee MDPI, Basel, Switzerland. This article is an open access article distributed under the terms and conditions of the Creative Commons Attribution (CC BY) license (https:// creativecommons.org/licenses/by/ $4.0 /)$.

\begin{abstract}
Crop residues can serve as low-cost feedstocks for microbial production of xylitol, which offers many advantages over the commonly used chemical process. However, enhancing the efficiency of xylitol fermentation is still a barrier to industrial implementation. In this study, the effects of oxygen transfer rate (OTR) $\left(1.1,2.1,3.1 \mathrm{mmol} \mathrm{O}_{2} /(\mathrm{L} \times \mathrm{h})\right)$ and initial xylose concentration $(30,55$, $80 \mathrm{~g} / \mathrm{L}$ ) on xylitol production of Candida boidinii NCAIM Y.01308 on xylose medium were investigated and optimised by response surface methodology, and xylitol fermentations were performed on xylose-rich hydrolysates of wheat bran and rice straw. High values of maximum xylitol yields (58-63\%) were achieved at low initial xylose concentration $(20-30 \mathrm{~g} / \mathrm{L})$ and OTR values (1.1-1.5 mmol $\left.\mathrm{O}_{2} /(\mathrm{L} \times \mathrm{h})\right)$. The highest value for maximum xylitol productivity $(0.96 \mathrm{~g} /(\mathrm{L} \times \mathrm{h}))$ was predicted at $71 \mathrm{~g} / \mathrm{L}$ initial xylose and $2.7 \mathrm{mmol} \mathrm{O}_{2} /(\mathrm{L} \times \mathrm{h})$ OTR. Maximum xylitol yield and productivity obtained on wheat bran hydrolysate were $60 \%$ and $0.58 \mathrm{~g} /(\mathrm{L} \times \mathrm{h})$, respectively. On detoxified and supplemented hydrolysate of rice straw, maximum xylitol yield and productivity of $30 \%$ and $0.19 \mathrm{~g} /(\mathrm{L} \times \mathrm{h})$ were achieved. This study revealed the terms affecting the xylitol production by C. boidinii and provided validated models to predict the achievable xylitol yields and productivities under different conditions. Efficient pre-treatments for xylose-rich hydrolysates from rice straw and wheat bran were selected. Fermentation using wheat bran hydrolysate and C. boidinii under optimized condition is proved as a promising method for biotechnological xylitol production.
\end{abstract}

Keywords: wheat bran; rice straw; acidic hydrolysis; fermentation; aeration; detoxification

\section{Introduction}

Biotechnological valorization of lignocellulosic residues derived from the agro-industrial sector is of great importance in many countries with intense agriculture in order to deal with the increasing demand of the society for energy and materials, the mitigation of greenhouse gas emissions and waste production and the development of a bio-based circular economy [1]. For such a sustainable bio-based economy, biorefineries that provide integrated facilities to produce a wide range of bio-products and bioenergy from biomass residues within a zero waste approach are considered as main pillars [2]. Around 4.6 billion tonnes of lignocellulosic biomass are produced annually as agricultural residues worldwide, of which only about $25 \%$ are used intensively [3,4]. However, they could serve as cheap, renewable and widely available raw materials for biorefineries [5].

Wheat (Triticum aestivum) and rice (Oryza sativa) are considered the most important crops in the human diet by contributing about $20 \%$ and $19 \%$ of the average calorie intake at global level, respectively [6]. The current worldwide production of wheat and rice are estimated at around 760 and 500 million tonnes, respectively, by FAO [7,8]. Moreover, increased demands for wheat and rice in the near future are usually predicted $[9,10]$. Hence, 
the intense cultivation and processing of these crops generate huge amount of lignocellulosic by-products having the potential to be valorized in biorefinery processes $[10,11]$. Wheat bran and rice straw are the main lignocellulosic by-products of wheat-milling and rice-harvesting processes, with an estimated global production of 150 and 730 million tonnes per year, respectively $[12,13]$. They contain a considerable amount of xylan-type hemicellulose fractions besides cellulose and lignin $[14,15]$. In an appropriate biorefinery process, the main constituents of the lignocellulosic raw material (cellulose, hemicellulose, lignin, protein etc.) can be sharply separated and converted into high-value platform chemicals, bio-products and energy [16]. Due to the relatively high xylan content of wheat bran and rice straw, one of the most promising platform chemicals that can be produced from them in a biorefinery is xylitol $[17,18]$.

Xylitol is a five-carbon polyol that is mainly used in the food industry as an alternative sweetener. It has an equivalent sweetness to sucrose but with lower caloric value and glycemic index. It is an ideal sweetener for diabetics because its metabolism is independent of insulin $[19,20]$. Moreover, due to its other specific properties, it is extensively used in personal health products such as mouthwash and toothpaste [21]. It is also used in cosmetics and by the pharmaceutical industry as therapeutic or coating agents [22]. Xylitol is currently produced by the chemical reduction of xylose on an industrial scale. However, a high purity of xylose is required for the chemical reduction process to avoid the formation of by-products (e.g., arabitol). Thus an extensive xylose purification step is inevitable prior to the chemical reduction, which contributes to the high production cost of xylitol $[23,24]$. On the other hand, xylitol can be produced by a microbial process. The microbial reduction takes place under mild conditions (in terms of pressure and temperature), and it does not require highly pure xylose as a carbon substrate, thus allowing the direct utilization of hemicellulosic hydrolysates that contain a mixture of sugars [25]. There are several microorganisms among bacteria, yeasts, and fungi with the capability of producing xylitol, though, the most efficient species belong to yeasts of Candida, such as C. tropicalis, C. guilliermondi, and C. boidinii [26]. However, there are several factors (e.g., pH, temperature, aeration, initial substrate concentration, inoculum level, medium composition etc.) affecting the xylitol fermentation. Oxygen supply and initial substrate concentration are considered as critical variables $[27,28]$. For the efficient production of xylitol, yeasts usually require a so-called micro-aerobic condition, providing oxygen limitation during the xylitol formation phase of the fermentation. The aeration conditions are usually characterized by the oxygen transfer rate (OTR) or oxygen mass transfer coefficient $\left(k_{L} a\right)$ of the fermentation system applied. The optimal OTR for xylitol production strongly depends on the yeast strain and fermentation medium applied, so it has to be determined in every case. Moreover, it can be affected by other fermentation parameters as well. Interestingly, the possible interactions between the fermentation parameters affecting the xylitol production are poorly investigated in the literature on this topic. Many studies reported that high xylose concentration can strongly inhibit xylitol production [29,30]; however, possible explanations were usually only hypothesized. Further investigations on the effects of the initial substrate concentration and its interaction with other fermentation parameters are still required in order to provide a proper explanation of the phenomena. Xylose-rich, hemicellulosic hydrolysates derived from the pre-treatment or fractionation processes of lignocellulosic residues are promising raw materials for biotechnological xylitol production [31].

In this study, the effects of initial xylose concentration and aeration on the xylitol production of Candida boidinii were investigated and the xylitol production was optimised. In addition, xylose-rich hydrolysates derived from acidic pre-treatments of wheat bran and rice straw were characterized and tested in xylitol fermentation by C. boidinii. This study revealed the main factors affecting the xylitol production of $C$. boidinii and provided validated models to predict xylitol yield and productivity depending on the initial xylose concentration and OTR. Moreover, promising methods to obtain xylose-rich hydrolysates 
from rice straw and wheat bran were selected and xylitol production under the most favorable conditions was successfully performed.

\section{Materials and Methods}

\subsection{Microorganism}

Candida boidinii NCAIM Y.01308 was purchased from the National Collection of Agricultural and Industrial Microorganisms (Budapest, Hungary). The strain was maintained at $4{ }^{\circ} \mathrm{C}$ on malt agar slants: $2 w / w \%$ malt extract and $2 w / w \%$ agar.

\subsection{Lignocellulosic Materials}

Wheat bran was provided from Gyermelyi Ltd. (Gyermely, Hungary). Ground rice straw (average particle size of $1.42 \mathrm{~mm}$ ) was provided from Suranaree University of Technology (Nakhon Ratchasima, Thailand). Wheat bran and rice straw had dry matter contents of $91.6 \%$ and $91.2 \%$, respectively, and they were stored at room temperature.

\subsection{Compositional Analysis}

The amounts of structural carbohydrates (glucan, xylan and arabinan) and lignin in rice straw and wheat bran regarding their dry matter content $(w / w \%)$ were determined according to the method published by the National Renewable Energy Laboratory [32]. Determination of the protein content of the raw materials was performed by using the Dumas method [33]. The inorganic content was determined gravimetrically after incineration of the raw materials in muffle furnace equipped with a ramping program [34].

The ground rice straw contained $38.8 \%$ glucan, $19.4 \%$ xylan, $3.8 \%$ arabinan, $14.0 \%$ lignin, $3.7 \%$ protein, and $13.2 \%$ inorganic compounds ( $w / w$, on dry basis). Wheat bran contained $26.6 \%$ glucan, $16.8 \%$ xylan, $9.5 \%$ arabinan, $6.4 \%$ lignin $17.4 \%$ protein, and $5.7 \%$ inorganic compounds ( $w / w$, on dry basis).

\subsection{Preparation of Xylose-Rich Hydrolysates from Wheat Bran and Rice Straw}

Xylose-rich hydrolysates from ground and fine ground rice straw samples were prepared by using phosphoric and sulfuric acids. Ground rice straw (average particle size: $1.42 \mathrm{~mm}$ ) was treated in a blade grinder for $10 \mathrm{~min}$ to obtain the fine ground rice straw (average particle size $0.67 \mathrm{~mm}$ ). The phosphoric acid treatment of ground and fine ground rice straws was performed according to the method of Jampatesh et al. [35]. Briefly, ground and fine ground rice straw samples were soaked in $2 \mathrm{~N}$ phosphoric acid for $4 \mathrm{~h}$ at room temperature and $220 \mathrm{rpm}$. The dry matter (DM) content of the reaction mixtures was $10 w / v \%$. (Thus, the obtained reaction mixtures contained $5.9 w / w \%$ phosphoric acid.) After the soaking, the reaction mixtures were treated in autoclave at $121^{\circ} \mathrm{C}$ for $30 \mathrm{~min}$ and then filtered through a nylon filter with $50 \mu \mathrm{m}$ pore size to separate the obtained xylose-rich hydrolysates and the remaining solid fractions. The xylose-rich hydrolysates derived from the phosphoric acid treatments of ground and fine ground rice straws are referred to as GRS/P and FGRS/P, respectively. The sulfuric acid pre-treatments of ground and fine ground rice straws were performed in reaction mixtures containing $1.5 w / w \%$ sulfuric acid and $10 w / w \%$ DM content. The reaction mixtures were treated in autoclave at $121{ }^{\circ} \mathrm{C}$ for $30 \mathrm{~min}$. Then the xylose-rich supernatants were separated from the solid fractions by using a nylon filter with $50 \mu \mathrm{m}$ pore size. The xylose-rich hydrolysates derived from the sulfuric acid treatment of ground and fine ground rice straws are referred to as GRS/S and FGRS/S, respectively. Xylose-rich hydrolysates from wheat bran were prepared following a two-step acidic hydrolysis process detailed in our previous study [17]. Briefly, wheat bran (10 w/w\% $\mathrm{DM}$ ) was treated in the first step in a $90{ }^{\circ} \mathrm{C}$ water bath by using $1.16 w / w \%$ sulfuric acid for $50 \mathrm{~min}$ or $1.61 \mathrm{w} / \mathrm{w} \%$ sulfuric acid for $47 \mathrm{~min}$, resulting in solid residues referred to as WBI and WBII, respectively. In the second step, WBI and WBII $(7.5 \% w / w$ DM) were treated by using $1 \mathrm{w} / \mathrm{w} \%$ sulfuric acid solution in an autoclave for $30 \mathrm{~min}$ at $121^{\circ} \mathrm{C}$ in order to obtain xylose-rich hydrolysates referred to as WB1/S and WB2/S, respectively. WB1/S and WB2/S were separated from the solid residues by using a nylon filter with $50 \mu \mathrm{m}$ pore 
size. The conditions of the acidic hydrolyses of ground and fine ground rice straws and wheat bran are summarized in Table 1. Xylose-rich hydrolysates of GRS/S and WB1/S were used for xylitol fermentation experiments.

Table 1. Different pre-treatment methods of rice straw and wheat bran for xylose-rich hydrolysates.

\begin{tabular}{|c|c|c|c|c|}
\hline \multirow{2}{*}{ Type of Acid } & \multirow{2}{*}{ Raw Material } & \multicolumn{2}{|r|}{ Treatments } & \multirow{2}{*}{$\begin{array}{l}\text { Xylose-Rich } \\
\text { Hydrolysate }\end{array}$} \\
\hline & & First Step & Second Step & \\
\hline \multirow[t]{2}{*}{$\mathrm{H}_{3} \mathrm{PO}_{4}$} & $\begin{array}{l}\text { ground } \\
\text { rice straw }\end{array}$ & $\begin{array}{l}\text { soaking }(10 \% \mathrm{DM} \text {, } \\
\left.2 \mathrm{~N} \text { acid, } 4 \mathrm{~h}, 25^{\circ} \mathrm{C}\right)\end{array}$ & in autoclave (soaked slurry, $121^{\circ} \mathrm{C}, 30 \mathrm{~min}$ ) & GRS/P \\
\hline & $\begin{array}{l}\text { fine ground } \\
\text { rice straw }\end{array}$ & $\begin{array}{l}\text { soaking }(10 \% \mathrm{DM} \text {, } \\
\left.2 \mathrm{~N} \text { acid, } 4 \mathrm{~h}, 25^{\circ} \mathrm{C}\right)\end{array}$ & in autoclave (soaked slurry, $121^{\circ} \mathrm{C}, 30 \mathrm{~min}$ ) & FGRS/P \\
\hline \multirow{4}{*}{$\mathrm{H}_{2} \mathrm{SO}_{4}$} & $\begin{array}{l}\text { ground } \\
\text { rice straw }\end{array}$ & $\begin{array}{l}\text { in autoclave ( } 10 \% \mathrm{DM}, \\
\left.1.5 \% \text { acid, } 121^{\circ} \mathrm{C}, 30 \mathrm{~min}\right)\end{array}$ & - & GRS/S \\
\hline & $\begin{array}{l}\text { fine ground } \\
\text { rice straw }\end{array}$ & $\begin{array}{l}\text { in autoclave }(10 \% \mathrm{DM}, \\
\left.1.5 \% \text { acid, } 121^{\circ} \mathrm{C}, 30 \mathrm{~min}\right)\end{array}$ & - & FGRS/S \\
\hline & wheat bran & $\begin{array}{c}\text { in water bath }(10 \% \mathrm{DM} \text {, } \\
\left.90^{\circ} \mathrm{C}, 1.16 \% \text { acid, } 50 \mathrm{~min}\right)\end{array}$ & $\begin{array}{l}\text { in autoclave (first solid residue, } 7.5 \% \mathrm{DM} \text {, } \\
1 \% \text { acid sol., } 121^{\circ} \mathrm{C}, 30 \mathrm{~min} \text { ) }\end{array}$ & WB1/S \\
\hline & wheat bran & $\begin{array}{c}\text { in water bath (10\% DM, } \\
\left.90^{\circ} \mathrm{C}, 1.61 \% \text { acid, } 47 \mathrm{~min}\right)\end{array}$ & $\begin{array}{c}\text { in autoclave (first solid residue, } 7.5 \% \mathrm{DM} \text {, } \\
1 \% \text { acid sol., } 121^{\circ} \mathrm{C}, 30 \mathrm{~min} \text { ) }\end{array}$ & $\mathrm{WB} 2 / \mathrm{S}$ \\
\hline
\end{tabular}

\subsection{Treatments and Supplementations of the Xylose-Rich Hydrolysates before Xylitol Fermentation}

The pHs of GRS/S and WB1/S were adjusted to 6 by adding $\mathrm{Ca}(\mathrm{OH})_{2}$, and the precipitated gypsum was removed by filtration (filter paper). In certain cases, the rice straw hydrolysate (GRS/S) was supplemented with $2 \mathrm{~g} / \mathrm{L}$ ammonium-sulphate or peptone. A combined treatment of GRS/S including a clarification by activated carbon and a subsequent supplementation with $2 \mathrm{~g} / \mathrm{L}$ peptone was also tested. The clarification was performed by using $5 w / w \%$ activated carbon (Norit DX ULTRA 8005.3) for 30 min with continuous stirring. The activated carbon was then separated by filtration through paper filter. After the treatments described above, all of the hydrolysates were sterilized in autoclave at $121{ }^{\circ} \mathrm{C}$ for $20 \mathrm{~min}$.

\subsection{Inoculum Preparation}

A single colony of Candida boidinii NCAIM Y.01308 was transferred from the malt agar slants into glucose agar ( $1 \mathrm{w} / \mathrm{v} \%$ glucose, $1 \mathrm{w} / \mathrm{v} \%$ peptone, $0.3 \mathrm{w} / \mathrm{v} \%$ yeast extract, and $2 \mathrm{w} / \mathrm{v} \%$ agar) and propagated for three days at room temperature. Then the cells were transferred into the inoculum medium ( $\mathrm{pH}$ 6) containing $10 \mathrm{~g} / \mathrm{L}$ yeast extract, $15 \mathrm{~g} / \mathrm{L} \mathrm{KH}_{2} \mathrm{PO}_{4}, 1 \mathrm{~g} / \mathrm{L}$ $\mathrm{MgSO}_{4} .7 \mathrm{H}_{2} \mathrm{O}, 3 \mathrm{~g} / \mathrm{L}\left(\mathrm{NH}_{4}\right)_{2} \mathrm{HPO}_{4}$, and $30 \mathrm{~g} / \mathrm{L}$ xylose. The cells were propagated in the inoculum medium for $72 \mathrm{~h}$ at $220 \mathrm{rpm}$ and $30^{\circ} \mathrm{C}$.

\subsection{Xylitol Fermentation}

Xylitol fermentation experiments were performed using Candida boidinii NCAIM Y.01540 in shake flasks. Xylitol fermentation on a semi-defined xylose medium was carried out in $100 \mathrm{~mL}$-shake flasks containing 35,50 , or $65 \mathrm{~mL}$ medium $(\mathrm{pH} 6)$ at $30{ }^{\circ} \mathrm{C}$ in a rotary shaker $(125 \mathrm{rpm})$ for $96 \mathrm{~h}$. The semi-defined xylose medium contained $10 \mathrm{~g} / \mathrm{L}$ yeast extract, $15 \mathrm{~g} / \mathrm{L} \mathrm{KH}_{2} \mathrm{PO}_{4}, 1 \mathrm{~g} / \mathrm{L} \mathrm{MgSO}{ }_{4} .7 \mathrm{H}_{2} \mathrm{O}, 3 \mathrm{~g} / \mathrm{L}\left(\mathrm{NH}_{4}\right)_{2} \mathrm{HPO}_{4}$ and 30, 55, or $80 \mathrm{~g} / \mathrm{L}$ xylose. Before inoculation, the solutions containing the xylose and other components were sterilized in an autoclave $\left(121^{\circ} \mathrm{C}, 20 \mathrm{~min}\right)$ separately to avoid the Maillard reaction. Initial cell concentrations were $5 \mathrm{~g}$ (dry cell mass)/L. The experiments were carried out according to designed experiments (Table 2). The experiments for model validation were carried out in duplicates. 
Table 2. Results of xylitol fermentation during the designed experiments $\left(3^{2}\right)$ by using Candida boidinii NCAIM Y.01308. (OTR: oxygen transfer rate, IXC: initial xylose concentration).

\begin{tabular}{|c|c|c|c|c|c|c|c|c|}
\hline OTR & $\begin{array}{c}\text { IXC } \\
\text { (Nominal } \\
\text { Values) }\end{array}$ & $\begin{array}{c}\text { Max. } \\
\text { Xylitol } \\
\text { Yield }\end{array}$ & $\begin{array}{l}\text { Time of Max. } \\
\text { Xylitol Yield }\end{array}$ & $\begin{array}{l}\text { Max. Xylitol } \\
\text { Productivity }\end{array}$ & $\begin{array}{c}\text { 24-h } \\
\text { Xylitol } \\
\text { Yield }\end{array}$ & $\begin{array}{c}\text { Xylose at } \\
\text { Max. Xylitol } \\
\text { Yield }\end{array}$ & $\begin{array}{l}\text { Spec. Xylitol } \\
\text { Yield at Max. } \\
\text { Xylitol Yield }\end{array}$ & $\begin{array}{c}\text { Max. } \\
\text { Ethanol }\end{array}$ \\
\hline $\begin{array}{c}\text { mmol } \\
\mathrm{O}_{2} /(\mathrm{L} \times \mathrm{h})\end{array}$ & $\mathrm{g} / \mathrm{L}$ & $\%$ & h & $\mathrm{g} /(\mathbf{L} \times \mathbf{h})$ & $\%$ & $\mathrm{~g} / \mathrm{L}$ & $\mathrm{g} / \mathrm{g}$ & $\mathrm{g} / \mathrm{L}$ \\
\hline 3.1 & 30 & 49 & 24 & 0.61 & 49 * & 3 & 0.55 & 4 \\
\hline 2.1 & 30 & 58 & 24 & 0.66 & $58 *$ & 4.5 & 0.71 & 2.7 \\
\hline 1.1 & 30 & 58 & 48 & 0.49 & 41 & 1.4 & 0.61 & 2 \\
\hline 3.1 & 55 & 42 & 72 & 0.88 & 35 & 0.2 & 0.43 & 2 \\
\hline 2.1 & 55 & 50 & 72 & 0.88 & 39 & 0.5 & 0.51 & 6.1 \\
\hline 2.1 & 55 & 48 & 72 & 0.91 & 40 & 0.4 & 0.49 & 5.9 \\
\hline 2.1 & 55 & 49 & 72 & 0.92 & 40 & 0.6 & 0.5 & 6 \\
\hline 1.1 & 55 & 52 & 72 & 0.59 & 26 & 5.3 & 0.58 & 5.7 \\
\hline 3.1 & 80 & 34 & 96 & 0.93 & 27 & 9.7 & 0.39 & 3.1 \\
\hline 2.1 & 80 & 36 & 96 & 0.87 & 26 & 19.8 & 0.49 & 5.9 \\
\hline 1.1 & 80 & 39 & 96 & 0.6 & 18 & 30.3 & 0.64 & 2.8 \\
\hline
\end{tabular}

${ }^{*}$ Equal to the maximum xylitol yield.

Xylitol fermentations on xylose-rich hydrolysates of wheat bran and rice straw (WB1/S, GRS/S, and GRS/S supplemented with ammonium-sulphate; GRS/S supplemented with peptone, and GRS/S clarified by activated carbon and supplemented with peptone) were performed in 100-mL shake flasks filled with $50 \mathrm{~mL}$ hydrolysates at $30^{\circ} \mathrm{C}$ in a rotary shaker (125 rpm) for $96 \mathrm{~h}$. The initial cell concentrations were $5 \mathrm{~g}$ (dry cell mass)/L.

All the fermentations were monitored by taking and analyzing samples every $24 \mathrm{~h}$. The samples were analyzed by spectrophotometer for optical density and high-performance liquid chromatography (HPLC) for sugars, alcohols and organic acids.

\subsection{Analytical Methods}

2.8.1. Concentration of Sugars, Alcohols, Organic Acids, Phenols, and Total Protein

Concentrations of glucose, xylose, arabinose, xylitol, ethanol, acetic acid, formic acid, furfural, and hydroxymethylfurfural (HMF) were determined by HPLC using BioRad (Hercules, CA, USA) Aminex HPX-87H $(300 \times 7.8 \mathrm{~mm})$ column equipped with MicroGuard Cation H+ Refill Cartridge $(30 \times 4.6 \mathrm{~mm})$ pre-column at $65^{\circ} \mathrm{C}$, and a refractive index detector. The eluent was $5 \mathrm{mmol} / \mathrm{L}$ sulfuric acid at a flow rate of $0.5 \mathrm{~mL} / \mathrm{min}$. The injection volume was $40 \mu \mathrm{L}$. Due to the overlapping peaks of xylose and galactose, those sugars were determined as one component in the xylose-rich hydrolysates of wheat bran and rice straw. It was referred to as xylose throughout the text because of the low concentration of galactose expected in the hydrolysates $[14,36]$. The total phenol content was determined by the Folin-Ciocalteu (FC) reagent according to the method described by Guo et al. [37]. The total protein content of the hydrolysates was determined by the Bradford method [38].

\subsubsection{Cell Concentration}

The cell concentration in fermentation samples was determined by measuring the optical density at a wavelength of $600 \mathrm{~nm}$ by spectrophotometer (Ultrospec III, Pharmacia LKB, Uppsala, Sweden). The cell concentration was calculated by using a calibration curve based on the relationship of optical density and cell dry weight [39].

\subsubsection{Thin-Layer Chromatography}

Thin-layer chromatography (TLC) was performed to qualitatively analyse the xylooligomeric composition of liquid samples. The samples $(5 \mu \mathrm{L})$ and the standard mixture $(5 \mu \mathrm{L})$ containing xylose and xylo-oligosaccharides (DP2-DP6) (Megazyme, Bray, Ireland) were dotted on a silica gel plate. The analysis was performed using butanol/acetic 
acid/water (2:1:1) as running solvent and revealed by water/ethanol/sulfuric acid (20:70:3) solution with $1 \% v / v$ orcinol over flame [40].

\subsubsection{Determination of Oxygen Transfer Rate}

Oxygen transfer rate (OTR) in shake-flask fermentation systems was determined by multiplying the maximum level of dissolved oxygen concentration $\left(C^{*}\right)$ achievable and the gas-liquid mass transfer coefficients $\left(\mathrm{k}_{\mathrm{L}} \mathrm{a}\right)$. The $\mathrm{C}^{*}$ was determined by optical oxygen sensor (VisiFerm DO 120, HAMILTON Bonaduz AG, Switzerland) in shake flasks containing semidefined xylose medium or xylose-rich hydrolysates (WB1/S, GRS/S) at $30{ }^{\circ} \mathrm{C}$. The $\mathrm{k}_{\mathrm{L}} \mathrm{a}$ was determined by a non-fermentative gassing-out method [41]. Dissolved oxygen was removed from the fermentation medium by bubbling it with nitrogen gas. After that, the headspace of the flasks was washed out with air, and the shaking was restarted. Then the dissolved oxygen concentration was continuously increased until reaching a constant value (maximum level of dissolved oxygen concentration $\left(C^{*}\right)$ ). The expression of $-\ln \left(1-\left(C / C^{*}\right)\right)$ was plotted as a function of time, where $C$ is the actual dissolved oxygen concentration at that given point in time. A linear curve was fitted to the plotted data. The slope of the fitted linear curve was equal to the value of $\mathrm{k}_{\mathrm{L}}$ a [42]. The OTR in 100-mL shake flasks filled with 35,50 , and $65 \mathrm{~mL}$ semi-defined xylose medium were $1.1(0.1), 2.1(0.1)$, and $3.1(0.1) \mathrm{mmol}$ $\mathrm{O}_{2} /(\mathrm{L} \times \mathrm{h})$, respectively, with the standard deviations indicated in parenthesis. The OTR values of the wheat bran and rice straw hydrolysates were $1.6(0.2)$ and $2.1(0.2) \mathrm{mmol}$ $\mathrm{O}_{2} /(\mathrm{L} \times \mathrm{h})$, respectively. OTR values of $1.1,2.1$, and $3.1 \mathrm{mmol} \mathrm{O}_{2} /(\mathrm{L} \times \mathrm{h})$ in semi-defined medium correspond to $\mathrm{k}_{\mathrm{L}}$ a values of 5,10 , and $15(1 / \mathrm{h})$, respectively. OTR values of $1.6 \mathrm{mmol} \mathrm{O}_{2} /(\mathrm{L} \times \mathrm{h})$ in WB1/S and $2.1 \mathrm{mmol} \mathrm{O}_{2} /(\mathrm{L} \times \mathrm{h})$ in GRS/S correspond to $\mathrm{k}_{\mathrm{L}} \mathrm{a}$ values of 8 and $10(1 / \mathrm{h})$, respectively.

\subsection{Calculation of Xylose Yield, Xylitol Yield, Xylitol Volumetric Productivity, Specific Xylitol Yield and Combined Severity Factor}

Xylose yield obtained during the hydrolysis of wheat bran and rice straw was expressed as percentage of theoretical. Theoretical xylose yield was calculated from the composition of the raw material used by assuming a complete hydrolysis of its xylan content into xylose.

Xylitol yield achieved in xylitol fermentation experiments was also expressed as percentage of theoretical. Theoretical xylitol yield was calculated from the initial xylose concentration by assuming a complete (stoichiometric) conversion into xylitol. Xylitol volumetric productivity $(\mathrm{g} /(\mathrm{L} \times \mathrm{h}))$ was calculated by dividing the xylitol concentration by the elapsed fermentation time. The specific xylitol yield was calculated as the amount of xylitol produced divided by the amount of xylose consumed and expressed as $\mathrm{g} / \mathrm{g}$.

In order to compare different pre-treatment methods, combined severity factor was calculated according to Wyman et al. [43].

\subsection{Statistical Evaluations and Optimisation}

A full factorial, orthogonal design of experiments $\left(3^{2}\right)$ with triplicates in the center point was performed in order to investigate the effects of two independent variables (OTR, initial xylose concentration) and their interactions on the maximum xylitol yield, maximum xylitol volumetric productivity and the xylitol yield after $24 \mathrm{~h}$ of fermentation. Maximum xylitol yield and maximum xylitol volumetric productivity refers to the highest values achieved during the given experiment. The results were evaluated by StatisticaTM v.13 (TIBCO Software, Palo Alto, USA) software. The settings of the two factors of initial xylose concentration and OTR value were the following: 30, 55, and $80 \mathrm{~g} / \mathrm{L}$ initial xylose concentration and 1.1, 2.1, and $3.1 \mathrm{mmol} \mathrm{O}_{2} /(\mathrm{L} \times \mathrm{h})$ OTR (Table 2). A quadratic polynomial model was fitted to the measured data. The adequacy of the model was tested with an F-test $(p=0.05)$. The fitted model is described by Equation (1).

$$
Y=\beta_{0}+\beta_{1} X_{1}+\beta_{2} X_{2}+\beta_{12} X_{1} X_{2}+\beta_{11} X_{1}^{2}+\beta_{22} X_{2}^{2}
$$


where $Y$ represents the response variable, $\beta_{0}$ is the interception coefficient, $b_{1}$ and $b_{2}$ are the linear terms, $\beta_{11}$ and $\beta_{22}$ are the quadratic terms and $X_{1}$ and $X_{2}$ represent the independent variables studied [44]. The model was reduced by non-significant terms, where it was possible. In the model equations, the original numerical values of OTR and initial xylose concentration were used without their units, and initial xylose concentration was referred to as IXC. The Pareto chart was also used to investigate the effects of the terms and interactions of the independent variables. Critical values of the fitted models were determined within the experimental range in order to find the optimum condition of xylitol fermentation.

To investigate the effect of the particle size of rice straw on the acidic hydrolysis, a grinding process was applied prior to acidic treatment, and the results were evaluated by one-way ANOVA analysis at a significance level of $5 \%$. It was performed by StatisticaTM v.13 (TIBCO Software, Palo Alto, USA) software.

\section{Results}

\subsection{Investigating the Effects of OTR and Initial Xylose Concentration on Xylitol Production by} Candida boidinii

In order to investigate the effects of initial xylose concentration and OTR on xylitol production, statistical analysis of the results of the designed experiments was performed (Table 2).

Three dependent parameters of the fermentation were evaluated: the maximum xylitol yield, the maximum xylitol volumetric productivity and the xylitol yield after $24 \mathrm{~h}$ (Table 2). Maximum xylitol yields were between 34-58, and the fitted model showed that the maximum xylitol yield was affected by the linear and quadratic terms of initial xylose concentration and by the linear term of OTR (Equation (2)). The maximum xylitol yields were reached at different times depending on the initial xylose concentration (Table 2). In general, they were obtained after 24,72 , and $96 \mathrm{~h}$ in the cases of 30,55, and $80 \mathrm{~g} / \mathrm{L}$ initial xylose concentrations, respectively, independent of the OTR applied. There was only one exception $\left(1.1 \mathrm{mmol} \mathrm{O}_{2} /(\mathrm{L} \times \mathrm{h})\right.$ of OTR and $30 \mathrm{~g} / \mathrm{L}$ initial xylose concentration) where the maximum xylitol yield was reached in $48 \mathrm{~h}$. The highest maximum xylitol yield (58\%) was obtained in the case of $30 \mathrm{~g} / \mathrm{L}$ initial xylose concentration with $2.1 \mathrm{mmol} \mathrm{O}_{2} /(\mathrm{L} \times \mathrm{h}) \mathrm{OTR}$ after $24 \mathrm{~h}$. The fitted surface (Figure 1A) clearly shows that high xylitol yields (58-63\%) can be achieved at low initial xylose concentrations (20-30 g/L) and OTR values (1.1-1.5 mmol $\left.\mathrm{O}_{2} /(\mathrm{L} \times \mathrm{h})\right)$. When 30 and $55 \mathrm{~g} / \mathrm{L}$ initial xylose concentrations were applied, only small amounts of xylose were remaining at the points of the maximum xylitol yields (Table 2). Maximum xylitol volumetric productivities were obtained after $24 \mathrm{~h}$ in all of the cases, and the values varied between 0.49 and $0.93 \mathrm{~g} /(\mathrm{L} \times \mathrm{h})$ (Table 2$)$. The statistical analysis showed that all of the terms (linear and quadratic terms of initial xylose concentration, linear and quadratic terms of OTR, and the interaction between the linear terms of initial xylose concentration and OTR) had a significant effect on the maximum xylitol volumetric productivity (Equation (3)). The fitted model predicted a highest value $(0.96 \mathrm{~g} / \mathrm{L} \times \mathrm{h})$ for maximum xylitol volumetric productivity in the case of $71.1 \mathrm{~g} / \mathrm{L}$ initial xylose concentration and $2.7 \mathrm{mmol} \mathrm{O}_{2} /(\mathrm{L} \times \mathrm{h}$ ) OTR (Figure 1B). Xylitol yields after $24 \mathrm{~h}$ of fermentation were also included in the evaluation in order to investigate the effects of the two independent factors at the time points of the maximum xylitol productivities. The maximum xylitol yield and the xylitol yield after $24 \mathrm{~h}$ were equal when the maximum xylitol yield was reached at $24 \mathrm{~h}$. However, this occurred in only two cases (initial xylose concentration $30 \mathrm{~g} / \mathrm{L}$ and OTR 3.1 or $2.1 \mathrm{mmol} \mathrm{O}_{2} /(\mathrm{L} \times \mathrm{h})$ ). All of the terms of the independent factors had significant effect on xylitol yield after $24 \mathrm{~h}$, except the term of the interaction between the linear terms of initial xylose concentration and OTR (Equation (4)). The fitted surface (Figure 1C) clearly shows that the optimal OTR range in terms of the xylitol yield after $24 \mathrm{~h}$ is between 2.0-2.5 $\mathrm{mmol} \mathrm{O}_{2} /(\mathrm{L} \times \mathrm{h})$. Hence, it is different than the optimal OTR range for the maximum xylitol yield $\left(1.0-1.5 \mathrm{mmol} \mathrm{O}_{2} /(\mathrm{L} \times \mathrm{h})\right.$ ). The fitted surface area (Figure 1C) also shows that the lower initial xylose concentration resulted in higher xylitol yield after $24 \mathrm{~h}$ which was similar to that experienced in the case of maximum xylitol yields. 
At the end of the fermentations, xylose was completely consumed in most of the cases, except in the cases of $80 \mathrm{~g} / \mathrm{L}$ initial xylose concentration, where $30.3,19.8$, and $9.7 \mathrm{~g} / \mathrm{L}$ xylose remained at OTR 1.1, 2.1 and $3.1 \mathrm{mmol} \mathrm{O}_{2} /(\mathrm{L} \times \mathrm{h})$, respectively (Figure S1). A small amount of xylose $(5.3 \mathrm{~g} / \mathrm{L})$ also remained in the case of $60 \mathrm{~g} / \mathrm{L}$ initial xylose concentration at $1.1 \mathrm{mmol} \mathrm{O}_{2} /(\mathrm{L} \times \mathrm{h})$ OTR (Figure S1). The cell concentrations increased by $0.5-1.9 \mathrm{~g} / \mathrm{L}$ throughout the fermentations, and they showed an increasing tendency by increasing the OTR (Figure S1). At the end of the fermentations, different ethanol concentrations were observed depending on the initial xylose concentration and OTR values applied (Table 2). The ethanol production was increased by increasing the initial xylose concentration and OTR. The highest ethanol concentration was $7.8 \mathrm{~g} / \mathrm{L}$ at $80 \mathrm{~g} / \mathrm{L}$ initial xylose concentration and $3.1 \mathrm{mmol} \mathrm{O}_{2} /(\mathrm{L} \times \mathrm{h})$ OTR (Table 2).

$$
\text { Maximum xylitol yield }=65.80+6.37 \times \text { OTR }-2.44 \times \mathrm{OTR}^{2}-0.37 \times \mathrm{IXC}
$$

Maximum xylitol volumetric productivity $=-0.48+0.59 \times \mathrm{OTR}-0.14 \times \mathrm{OTR}^{2}+0.02 \times \mathrm{IXC}-0.0002 \times \mathrm{IXC}^{2}+0.002 \times \mathrm{OTR} \times \mathrm{IXC}$

$$
\text { Xylitol yield after } 24 \mathrm{~h}=34.04+40.84 \times \text { OTR }-8.65 \times \mathrm{OTR}^{2}-1.02 \times \mathrm{IXC}+0.005 \times \mathrm{IXC}^{2}
$$

A
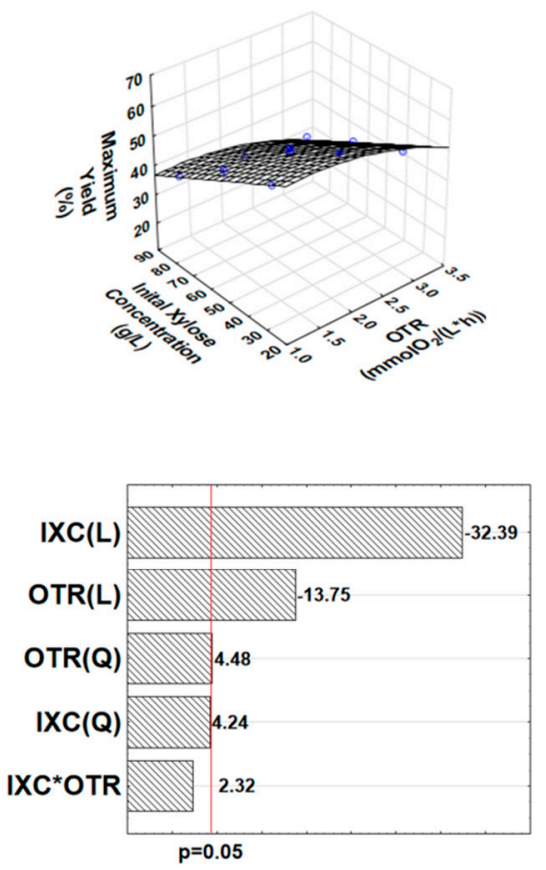

B
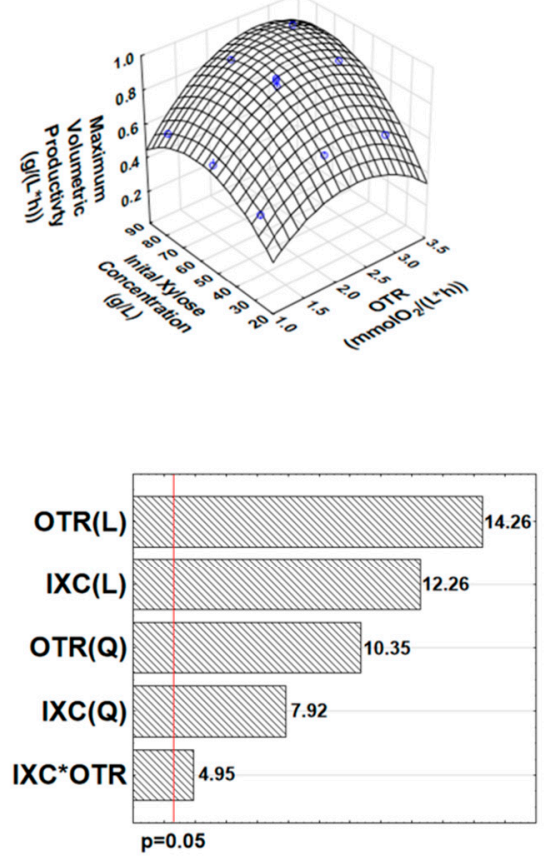

C
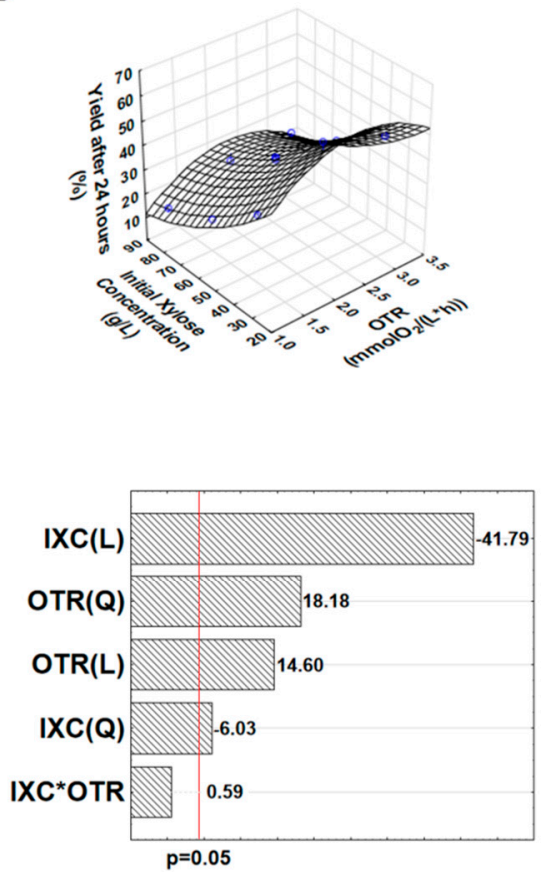

Figure 1. The fitted surface areas and Pareto charts of the evaluation of designed xylitol fermentation experiments using Candia boidinii NCAIM Y.01308. (A): maximum xylitol yield, (B): maximum xylitol volumetric productivity, (C): xylitol yield after 24 h. (OTR: oxygen transfer rate; IXC: initial xylose concentration).

In order to check the reproducibility of the fermentations and validate the fitted models, experiments were performed under two different conditions. In the first case, fermentations were performed under the conditions where the highest maximum xylitol yield was obtained during the designed experiments ( $30 \mathrm{~g} / \mathrm{L}$ initial xylose concentration, $2.1 \mathrm{mmol} \mathrm{O}_{2} /(\mathrm{L} \times \mathrm{h})$ OTR $)$. In the second case, a previously unmeasured point was selected, namely, $71 \mathrm{~g} / \mathrm{L}$ initial xylose concentration and $2.1 \mathrm{mmol}_{2} /(\mathrm{L} \times \mathrm{h}) \mathrm{OTR}$. This was near to the point where the highest maximum xylitol volumetric productivity was predicted by the model $\left(71.1 \mathrm{~g} / \mathrm{L}\right.$ initial xylose concentration, $2.7 \mathrm{mmol} \mathrm{O}_{2} /(\mathrm{L} \times \mathrm{h})$ ). Fermentation profiles of the validation experiments are shown in Figure 2. In the first 
case, $55 \%$ maximum xylitol yield and $0.75 \mathrm{~g} /(\mathrm{L} \times \mathrm{h})$ maximum xylitol productivity were achieved. The xylitol concentration reached its maximum value at $24 \mathrm{~h}$, and then, it slightly decreased until the end of the fermentation (Figure 2A). A small amount of ethanol was produced in the first $48 \mathrm{~h}(4.3 \mathrm{~g} / \mathrm{L})$; however, that was completely consumed by the cells until the end of the fermentation (Figure 2). The maximum productivity was also obtained after $24 \mathrm{~h}$. A small amount of xylose $(4.7 \mathrm{~g} / \mathrm{L})$ remained in the broth at this point, but it was completely depleted after $48 \mathrm{~h}$ (Figure 2A). The achieved xylitol yields and volumetric productivity are in accord with the ones predicted by the fitted model and previously obtained during the designed experiments (Tables 2 and 3), indicating the good reproducibility of the fermentations. All the results fitted into the predicted intervals of the models (Table 3 ). In the second case, $46 \%$ maximum xylitol yield, $32 \% 24-\mathrm{h}$ xylitol yield, and $1.01 \mathrm{~g} /(\mathrm{L} \times \mathrm{h})$ maximum xylitol productivity were achieved. These values are similar to that predicted by the fitted models, and all of them are in the prediction intervals (Table 3). The fermentation profile observed was quite different to that of the first case (Figure 2B). The xylitol concentration continuously increased, meanwhile the xylose concentration decreased until the end of the fermentation. In addition, a significant amount of ethanol was produced by the end of the fermentation $(13.8 \mathrm{~g} / \mathrm{L})$. In both cases, a small increase in the cell concentration $(0.8-1 \mathrm{~g} / \mathrm{L})$ was also observed. Based on the results of the verification experiment, it can be concluded that the fitted models are adequate and suitable for good predictions within the experimental range.

A

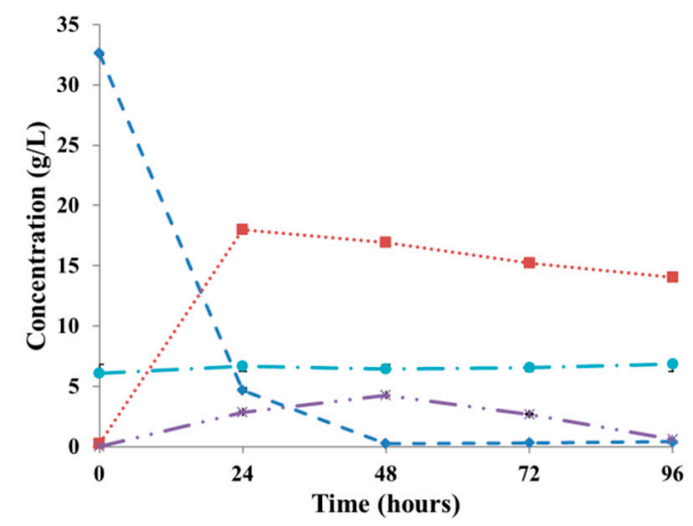

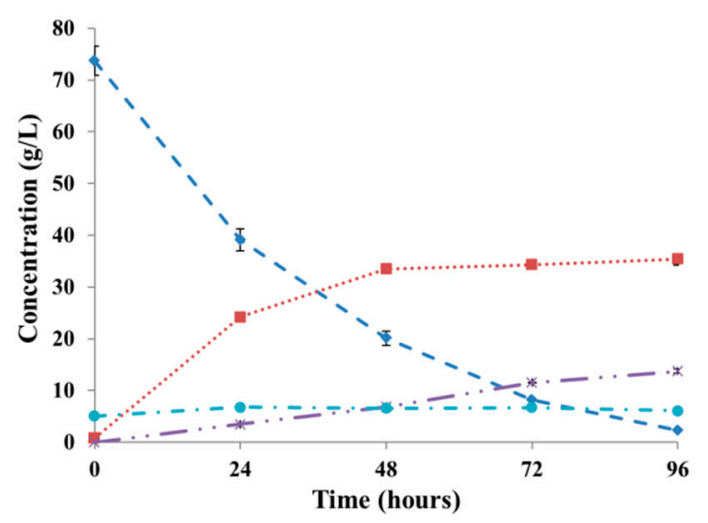

$\multimap$ Xylose $\cdots \boxminus \cdot \cdot$ Xylitol $\rightarrow \cdot$ EtOh $\rightarrow$ Cell mass

Figure 2. Profiles of fermentations performed at $2.1 \mathrm{mmol}_{2} /(\mathrm{L} \times \mathrm{h})$ OTR on semi-defined medium containing an initial xylose concentration of $30 \mathrm{~g} / \mathrm{L}$ (A) and $71 \mathrm{~g} / \mathrm{L}$ (B) using Candida boidinii Y.01308. Standard deviations are calculated from duplicates.

Table 3. Maximum xylitol yield, maximum xylitol volumetric productivity, and xylitol yield after $24 \mathrm{~h}$ of model predictions and experiments. (OTR: oxygen transfer rate, IXC: initial xylose concentration.)

\begin{tabular}{|c|c|c|c|c|c|c|}
\hline \multirow{2}{*}{$\begin{array}{l}\text { Conditions } \\
\text { Parameters }\end{array}$} & \multicolumn{3}{|c|}{$\begin{array}{c}30 \mathrm{~g} / \mathrm{L} \text { IXC, } 2.1 \mathrm{mmol} \mathrm{O}_{2} /(\mathrm{L} \times \mathrm{h}) \text { OTR, } \\
\text { Semi-Defined Medium }\end{array}$} & \multicolumn{3}{|c|}{$\begin{array}{c}71 \mathrm{~g} / \mathrm{L} \text { IXC, } 2.1 \mathrm{mmol} \mathrm{O}_{2} /(\mathrm{L} \times \mathrm{h}) \mathrm{OTR}, \\
\text { Semi-Defined Medium }\end{array}$} \\
\hline & $\begin{array}{l}\text { Max.. Xylitol } \\
\text { Yield }\end{array}$ & $\begin{array}{l}\text { Max. Xylitol } \\
\text { Productivity }\end{array}$ & $\begin{array}{l}\text { 24-h Xylitol } \\
\text { Yield }\end{array}$ & $\begin{array}{l}\text { Max. Xylitol } \\
\text { Yield }\end{array}$ & $\begin{array}{l}\text { Max. Xylitol } \\
\text { Productivity }\end{array}$ & $\begin{array}{l}\text { 24-h Xylitol } \\
\text { Yield }\end{array}$ \\
\hline & $\%$ & $\mathrm{~g} /(\mathrm{L} \times \mathrm{h})$ & $\%$ & $\%$ & $\mathrm{~g} /(\mathrm{L} \times \mathrm{h})$ & $\%$ \\
\hline Predicted & 57 & 0.68 & 55 & 42 & 0.92 & 32 \\
\hline $\begin{array}{l}95 \% \text { prediction } \\
\text { interval }\end{array}$ & $54-61$ & $0.57-0.79$ & $51-59$ & $39-46$ & $0.81-1.02$ & $29-36$ \\
\hline $\begin{array}{l}\text { Experimentally } \\
\text { obtained }\end{array}$ & $55(0.18)$ & $0.75(0.00)$ & $55(0.18)$ & 46 (1.67) & $1.01(0.01)$ & $32(1.43)$ \\
\hline
\end{tabular}




\subsection{Xylose-Rich Hydrolysates from Rice Straw and Wheat Bran}

In order to produce xylose-rich hydrolysates, acidic pre-treatments of wheat bran and rice straw were investigated. In the case of wheat bran, two-step sulfuric acid hydrolyses, suggested in our previous study [17], were performed, resulting in two types of xylose-rich hydrolysates (Table 1). In the case of rice straw, a phosphoric acid hydrolysis, proposed by Jampatesh et al. [35] as an optimal pre-treatment for succinate production and with high hemicellulose saccharification yield, was used. The effects of the particle size on the efficiency of phosphoric acid pre-treatment were evaluated by using ground (average particle size of $1.42 \mathrm{~mm}$ ) and fine ground (average particle size of $0.67 \mathrm{~mm}$ ) rice straw samples (Table 1). In addition, sulfuric acid pre-treatments of ground and fine ground rice straws under mild conditions were also examined (Table 1). In order to predict the applicability of those hydrolysates in xylitol fermentation experiments, the sugar compositions, amount of inhibitory compounds and protein content were evaluated. The sugar composition of the wheat bran hydrolysates were quite similar to that obtained previously [17] (Table 4); however, a higher amount of acetic acid (0.7-1 g/L (Table 4) compared to $0.3 \mathrm{~g} / \mathrm{L}$ [17]) was observed in this study. Interestingly, only phenolic substances were observed as inhibitory compounds beside acetic acid. Furfural, HMF and formic acid were not detected in the hydrolysates (Table 4). In addition, wheat bran hydrolysates contained relatively high amount of solubilized proteins $(7 \mathrm{~g} / \mathrm{L})$, which is advantageous in terms of their fermentability. WB1/S contained a slightly higher amount of xylose $(22.6 \mathrm{~g} / \mathrm{L})$ compared to WB2/S $(21.1 \mathrm{~g} / \mathrm{L})($ Table 4$)$; hence, WB1/S was selected for xylitol fermentation experiments. In the case of rice straw, sulfuric acid and phosphoric acid treatments by using ground and fine ground raw material were investigated, resulting in four different types of xylose-rich hydrolysate (Table 1). In the case of using phosphoric acid, glucose concentration of the hydrolysates was not quantified, because of the overlapping peaks of phosphoric acid and glucose in our HPLC analyses. The phosphoric acid treatment of ground and fine ground rice straws yielded relatively low xylose concentrations of $11.1 \mathrm{~g} / \mathrm{L}$ and $11.0 \mathrm{~g} / \mathrm{L}$, respectively. These concentrations correspond to the xylose yields of $69 \%$ and $68 \%$, respectively. The total concentration of furfural, formic acid, HMF and acetic acid was around $3 \mathrm{~g} / \mathrm{L}$ in both cases, which is similar to that obtained by Jampatesh et al. [35] under the same conditions. Besides those inhibitors, GRS/P and FGRS/P also contained considerable amounts of phenolic substances, resulting in total inhibitor concentrations of $4.5 \mathrm{~g} / \mathrm{L}$ and $4.2 \mathrm{~g} / \mathrm{L}$, respectively (Table 4). Comparing the xylose and different inhibitor concentrations of GRS/P and FGRS/P at 0.05 significance level, significant differences were not observed. Thus, it could be concluded that particle size of rice straw does not have a significant effect on the performance of the phosphoric acid hydrolysis within the investigated range. Sulfuric acid treatment of ground and fine ground rice straws resulted in $20.6 \mathrm{~g} / \mathrm{L}$ and $19.9 \mathrm{~g} / \mathrm{L}$ xylose, respectively. These values correspond to the xylose yields of $94 \%$ and $91 \%$, respectively, which are considerably higher than the xylose yields achieved during the phosphoric acid treatment. That could be partly because of an incomplete degradation of the solubilized xylan part in the case of the phosphoric acid treatment. Thin-layer chromatography analysis showed sharper spots for the xylo-oligosaccharides (DP 2-6) when phosphoric acid treatment was performed, suggesting an incomplete hydrolysis of xylan (Figure S2). When the severity factors of the two treatments were compared, a value of 1.3 was obtained for both treatments, suggesting that sulfuric acid is more efficient in decomposing hemicellulose completely. The total inhibitor concentrations of GRS/P and FGRS/P were $4.5 \mathrm{~g} / \mathrm{L}$ and $4.2 \mathrm{~g} / \mathrm{L}$, respectively (Table 4 ). Significant differences were not observed when the xylose and different inhibitor concentrations of GRS/S and FGRS/S were compared at 0.05 significance level. Thus, particle size had no significant effect on the quality of the sulfuric acid hydrolysates within the investigated range. The protein content of both the sulfuric acid- and phosphoric acid-catalyzed hydrolysates was very low (below $1 \mathrm{~g} / \mathrm{L}$ ) (Table 4). The hydrolysates from wheat bran seemed to be a better medium for xylitol production due to their higher xylose but lower inhibitor content, compared to the hydrolysates from rice straw. However, in terms of the concentration of other sugars, rice 
straw hydrolysates were more advantageous. They contained much less arabinose beside the xylose, which can enhance the purity of the fermented broth. GRS/P contained quite low xylose concentration, which would probably result in decreased xylitol production, thus only GRS/S was tested in xylitol fermentation beside WB1/S.

Table 4. Composition of different lignocellulosic hydrolysates.

\begin{tabular}{|c|c|c|c|c|c|c|}
\hline \multicolumn{7}{|c|}{ Composition (g/L) } \\
\hline & WB1/S & WB2/S & GRS/S & FGRS/S & GRS/P & FGRS/P \\
\hline Glucose & $0.8(0.1)$ & $1.0(0.0)$ & $5.5(0.1)$ & $5.3(0.3)$ & n.m. & n.m. \\
\hline Xylose & $22.6(1.3)$ & $21.1(0.4)$ & $20.6(0.7)$ & $19.9(0.5)$ & $11.1(0.5)$ & $11.0(0.2)$ \\
\hline Arabinose & $12.4(0.6)$ & $9.1(1.3)$ & $3.9(0.2)$ & $3.7(0.2)$ & $3.3(0.1)$ & $3.2(0.1)$ \\
\hline Protein & $7.3(0.3)$ & $7.0(0.4)$ & $0.3(0.0)$ & n.m. & $0.7(0.0)$ & n.m. \\
\hline Acetic acid & $1.0(0.1)$ & $0.8(0.0)$ & $2.4(0.2)$ & $2.4(0.1)$ & $1.6(0.1)$ & $1.3(0.0)$ \\
\hline Formic acid & n.d. & n.d. & $1.1(0.2)$ & $1.1(0.0)$ & $1.0(0.1)$ & $1.0(0.0)$ \\
\hline HMF & n.d. & n.d. & $0.5(0.1)$ & $0.5(0.0)$ & $0.6(0.0)$ & $0.5(0.0)$ \\
\hline Furfural & n.d. & n.d. & n.d. & n.d. & n.d. & n.d. \\
\hline Phenols & $1.4(0.1)$ & $1.4(0.1)$ & $1.4(0.3)$ & $1.7(0.1)$ & $1.3(0.1)$ & $1.4(0.0)$ \\
\hline Total inhibitors & 2.5 & 2.4 & 5.4 & 5.7 & 4.5 & 4.2 \\
\hline
\end{tabular}

n.m.: not measured; n.d.: not detected; Standard deviations are calculated from triplicates and presented in parentheses.

\subsection{Xylitol Fermentation on Xylose-Rich Hydrolysates of Rice Straw and Wheat Bran}

In Section 3.1, the effects of OTR and initial xylose concentration on the xylitol production of Candida boidinii were investigated. The applicability and adequacy of the models for maximum xylitol yield (Equation (2)), maximum xylitol volumetric productivity (Equation (3)), and xylitol yield after $24 \mathrm{~h}$ (Equation (4)), developed by using semi-defined medium, were also tested in the case of using xylose-rich hydrolysates derived from rice straw (GRS/S) and wheat bran (WB1/S). Xylitol fermentation experiments on the xyloserich hydrolysates were performed under the aeration condition that provided $2.1 \mathrm{mmol}$ $\mathrm{O}_{2} /(\mathrm{L} \times \mathrm{h}) \mathrm{OTR}$ value in the case of semi-defined medium. However, these conditions resulted in $1.6 \mathrm{mmol} \mathrm{O}_{2} /(\mathrm{L} \times \mathrm{h})$ OTR when WB1/S was used, probably due to the different chemical composition. Xylitol fermentation on WB1/S showed similar profile than that of the fermentation obtained by using semi-defined medium (30 g/L initial xylose, $2.1 \mathrm{mmol}$ $\mathrm{O}_{2} /(\mathrm{L} \times \mathrm{h}) \mathrm{OTR}$ ) (Figures $2 \mathrm{~A}$ and $\left.3 \mathrm{~A}\right)$; however, both the initial xylose concentration $(22.1 \mathrm{~g} / \mathrm{L})$ and the OTR $\left(1.6 \mathrm{mmol} \mathrm{O}_{2} /(\mathrm{L} \times \mathrm{h})\right)$ were a bit lower in the case of WB1/S. Maximum xylitol concentration $(14.2 \mathrm{~g} / \mathrm{L})$ was obtained at $24 \mathrm{~h}$, resulting in the maximum xylitol yield of $60 \%$ (spec. xylitol yield: $0.72 \mathrm{~g} / \mathrm{g}$ ) (Figure 3A). The maximum xylitol productivity was also reached after $24 \mathrm{~h}$, and it was $0.58 \mathrm{~g} /(\mathrm{L} \times \mathrm{h})$. Predictions for the maximum xylitol yield, xylitol yield after $24 \mathrm{~h}$, and maximum xylitol volumetric productivity were calculated by the previously fitted models (Equations (2)-(4)) using $22.1 \mathrm{~g} / \mathrm{L}$ initial xylose concentration and $1.6 \mathrm{mmol} \mathrm{O}_{2} /(\mathrm{L} \times \mathrm{h})$ OTR value as input parameters. The maximum xylitol yield was achieved also in $24 \mathrm{~h}$, thus it was equal to the xylitol yield after $24 \mathrm{~h}$. Due to the fact that different models were fitted to the maximum and 24-h xylitol yields, the models provided slightly different predictions for those response variables but with overlapping predicted intervals. The models predicted $61 \%$ maximum xylitol yield with a prediction interval of 58-65\%, and 57\% xylitol yield after $24 \mathrm{~h}$ with a prediction interval of 52-61\%. Thus, the experimentally measured xylitol yield (60\%) fitted in with the predictions of both models. Maximum xylitol productivity was estimated to be 0.49 $\mathrm{g} /(\mathrm{L} \times \mathrm{h})$ by the model with a prediction interval of $0.35-0.63 \mathrm{~g} /(\mathrm{L} \times \mathrm{h})$, showing a good agreement with the experimentally obtained value $(0.58 \mathrm{~g} /(\mathrm{L} \times \mathrm{h}))$. Therefore, the models developed by using semi-defined medium were found appropriate to provide adequate predictions for xylitol fermentations on WB1/S, indicating that wheat bran hydrolysate is a suitable raw material to produce xylitol by using Candida boidinii NCAIM Y.01308. Ethanol production was observed in both cases of using a semi-defined medium or WB1/S. The ethanol concentration reached its maximum in $48 \mathrm{~h}$, and then, ethanol was totally 
consumed by the end of the fermentation (Figures 2A and 3A). The growth of the cells was also similar in both cases. The cell concentrations increased by about $1 \mathrm{~g} / \mathrm{L}$ during the fermentations. The profiles of xylose decrease were also similar, except that a small amount of xylose seemed to remain in wheat bran hydrolysate (Figure $3 \mathrm{~A}$ ). It could be explained by the presence of small amount of galactose in the wheat bran hydrolysate [36], which could be detected as xylose due to the overlapping peaks in the HPLC analysis used in this study. Residual galactose during xylitol fermentation on corn fiber hydrolysate by Candida boidinii was observed in our previous study [39]. Xylitol fermentations were also performed on GRS/S under the same aeration condition, resulting in similar OTR value $\left(2.1 \mathrm{mmol} \mathrm{O}_{2} /(\mathrm{L} \times \mathrm{h})\right)$ to that measured in the semi-defined medium. The profile of the xylitol fermentation on GRS/S (Figure 3B) was different from that observed on the semi-defined medium or WB1/S. Although the initial xylose concentration was similar to that in WB1/S, the achieved maximum xylitol yield was significantly lower $(20 \%$, spec. xylitol yield: $0.26 \mathrm{~g} / \mathrm{g}$ ), and it was reached latter $(72 \mathrm{~h})$. The remaining xylose concentration $(3.4 \mathrm{~g} / \mathrm{L})$ at this point was similar to that observed in the cases of a semi-defined medium and WB1/S (Figures 2A and 3A,B). However, it could contain small amount of galactose as well, which was not analyzed in this study. The xylitol yield after $24 \mathrm{~h}(19 \%)$ was similar to the maximum xylitol yield (20\%), but at $24 \mathrm{~h}$, the remaining xylose concentration was much higher $(8 \mathrm{~g} / \mathrm{L})$. This is almost half of the initial xylose concentration and nearly twice of the xylose concentration measured in semi-defined medium and WB1/S after $24 \mathrm{~h}$ of fermentation (Figures $2 \mathrm{~A}$ and $3 \mathrm{~A}, \mathrm{~B})$. The maximum xylitol volumetric productivity obtained in $24 \mathrm{~h}$ was also very low $(0.14 \mathrm{~g} /(\mathrm{L} \times \mathrm{h}))$ compared to the previous fermentations. In the case of GRS/S, a higher amount of ethanol was produced ( $8.4 \mathrm{~g} / \mathrm{L}$ after $72 \mathrm{~h}$ ) compared to the previous cases. Moreover, ethanol production exceeded xylitol production (Figure 3B).
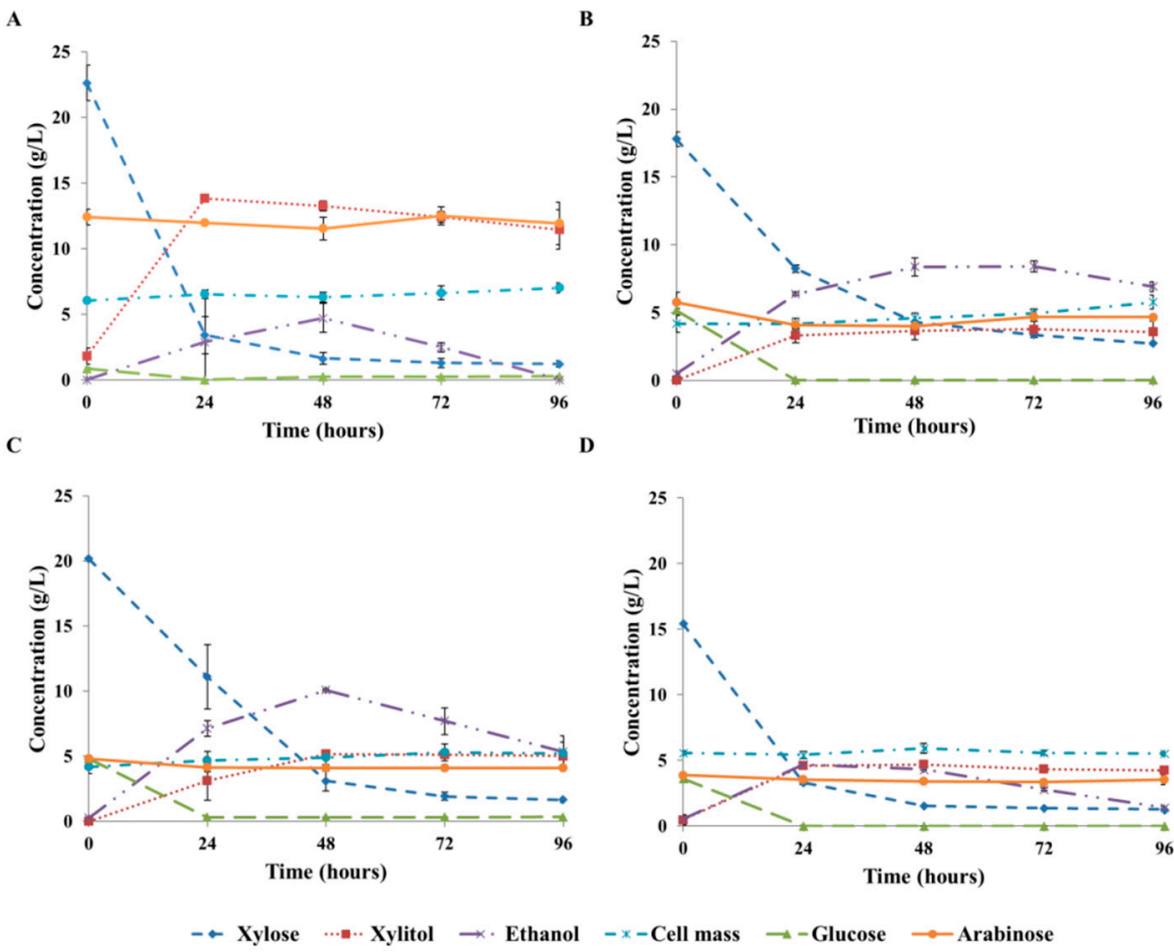

Figure 3. Profiles of the xylitol fermentations on WB1/S (A) GRS/S (B) GRS/S supplemented with $2 \mathrm{~g} / \mathrm{L}$ peptone $(\mathrm{C})$ and GRS/S treated by activated carbon and supplemented with $2 \mathrm{~g} / \mathrm{L}$ peptone (D) using Candida boidinii NCAIM Y.01308. Standard deviations are calculated from duplicates.

Since GRS/S hydrolysate had a low protein content (Table 4), supplementations with $2 \mathrm{~g} / \mathrm{L}$ of inorganic (ammonium sulphate) or organic (peptone) nitrogen sources were investigated with the aim of enhancing xylitol production. In the case of supplementation with ammonium-sulphate, the maximum xylitol yield was $15 \%$ (spec. xylitol yield: $0.22 \mathrm{~g} / \mathrm{g}$ 
at this point), and it was achieved after $48 \mathrm{~h}$ (data not shown). The xylitol yield after $24 \mathrm{~h}$ and the maximum xylitol productivity were $10 \%$ and $0.08 \mathrm{~g} /(\mathrm{L} \times \mathrm{h}$ ), respectively (data not shown). All of these results are lower than that achieved without supplementation. In contrast, the addition of peptone resulted in a small increase in maximum xylitol yield (25\%, (spec. xylitol yield: $0.30 \mathrm{~g} / \mathrm{g}$ at this point)), xylitol yield after $24 \mathrm{~h}(15 \%)$ and maximum xylitol volumetric productivity $(0.15 \mathrm{~g} /(\mathrm{L} \times \mathrm{h}))$ (Figure $3 \mathrm{C})$ as well. Hence, xylitol fermentation was slightly enhanced by adding peptone; however, ethanol concentration was also considerably increased. The ethanol concentration was $10 \mathrm{~g} / \mathrm{L}$ at $48 \mathrm{~h}$ beside only $5 \mathrm{~g} / \mathrm{L}$ of xylitol (Figure 3C).

To improve xylitol fermentation on GRS/S, activated carbon treatment was tested in addition to the supplementation with peptone. After the activated carbon treatment, detectable amount of phenols and HMF were not present in GRS/S. On the other hand, the amount of organic acids $(0.9 \mathrm{~g} / \mathrm{L}$ formic acid and $2.4 \mathrm{~g} / \mathrm{L}$ acetic acid) were not reduced significantly compared to the GRS/S without detoxification $(1.1 \mathrm{~g} / \mathrm{L}$ formic acid and $2.4 \mathrm{~g} / \mathrm{L}$ acetic acid). Moreover, the activated carbon treatment caused significant xylose loss, resulting in $15.4 \mathrm{~g} / \mathrm{L}$ initial xylose concentration. After the detoxification step, GRS/S was also supplemented by $2 \mathrm{~g} / \mathrm{L}$ peptone. Due to the activated carbon treatment, the maximum xylitol yield increased to $30 \%$ (spec. xylitol yield: $0.33 \mathrm{~g} / \mathrm{g}$ ), and it was reached after $48 \mathrm{~h}$. The xylitol yield after $24 \mathrm{~h}$ and the maximum xylitol productivity were $29 \%$ and $0.19 \mathrm{~g} /(\mathrm{L} \times \mathrm{h})$, respectively. All of these results are lower compared to those achieved on WB1/S or a semi-defined medium under similar aeration conditions. The ethanol production was reduced due to the detoxification step, resulting in only $4.7 \mathrm{~g} / \mathrm{L}$ ethanol concentration at the point of the maximum xylitol yield. This was a half of the ethanol produced in the hydrolysate without detoxification. The maximum specific xylitol yields were reached after $24 \mathrm{~h}$ in all fermentations on lignocellulosic hydrolysates. The specific xylitol yields were $0.35 \mathrm{~g} / \mathrm{g}, 0.24 \mathrm{~g} / \mathrm{g}, 0.35 \mathrm{~g} / \mathrm{g}$, and $0.38 \mathrm{~g} / \mathrm{g}$ in the cases of GRS/S, GRS/S supplemented with ammonium-sulphate, GRS/S supplemented with peptone, GRS/S clarified by activated carbon and supplemented with peptone, respectively. The cell concentrations increased by 1-1.8 g/L during the fermentations, except in the cases of GRS/S supplemented with peptone and detoxified GRS/S with peptone supplementation, where the cell mass did not change. Small amount of glucose (3.5-5 g/L) was also present in the rice straw hydrolysates, which was totally consumed after 24 h (Figure 3B-D).

\section{Discussion}

The effects of initial xylose concentration and aeration (OTR) on maximum xylitol yield, maximum xylitol volumetric productivity, and xylitol yield after $24 \mathrm{~h}$ were investigated first in this study, by using Candida boidinii NCAIM Y.01308 in a semi-defined xylose medium. Vandeska et al. [45] investigated the effect of the initial xylose concentration on the achievable xylitol yield during fermentation on a model xylose medium by C. boidinii NRRL Y17213. They varied the initial xylose concentration between 20 and $200 \mathrm{~g} / \mathrm{L}$ under the same aeration conditions (50 mL medium in 125 mL-flask, 150 rpm shaking), and concluded that the xylitol yield of 14 days fermentation continuously increased from $6 \%$ to the maximum value of $52 \%$ by increasing the initial xylose concentration from $20 \mathrm{~g} / \mathrm{L}$ to $150 \mathrm{~g} / \mathrm{L}$. Interestingly, initial xylose concentration of $200 \mathrm{~g} / \mathrm{L}$ significantly inhibited the xylitol fermentation. Vongsuvanlert and Tani [46] reported that a xylose concentration of $150 \mathrm{~g} / \mathrm{L}$ resulted in lower xylitol production than that of $100 \mathrm{~g} / \mathrm{L}$, when C. boidinii no. 2201 was used on xylose basal medium. They performed the fermentations in $500 \mathrm{~mL}$-flasks filled with $100 \mathrm{~mL}$ medium at $100 \mathrm{rpm}$ shaking. Those studies showed that under given conditions of aeration, increasing xylose concentration increased the xylitol production until a certain value above which it had a negative effect. Osmotic stress on the cells is often hypothesized as a possible reason for the negative effect of high xylose concentration $[46,47]$. However, in our study, a decreasing tendency in the xylitol yield was observed by increasing the xylose concentration under the investigated range of xylose concentration and aeration. Oxygen availability during xylitol fermentation is a key factor due to its 
influence on the intracellular redox balance. The key enzymes for assimilation of D-xylose in yeasts are the xylose reductase (XR), which catalyses the reduction of D-xylose to xylitol requiring $\mathrm{NAD}(\mathrm{P}) \mathrm{H}$ as cofactor, and the NAD-dependent xylitol dehydrogenase $(\mathrm{XDH})$ catalysing the xylitol conversion to xylulose [48]. Xylitol accumulation under microaerobic conditions is the result of a deficient NAD regeneration by the respiratory chain which leads to diminished XDH activity $[45,48]$. In addition, formation of certain by-products during the xylitol fermentation can also contribute to maintaining the intracellular cofactor balance [49]. Winkelhausen et al. [50] investigated the effect of different $\mathrm{k}_{\mathrm{L}}$ a values on the xylitol production of C. boidinni NRRL Y17213 in a xylose model medium using shake flasks (50 g/L initial xylose concentration) and fermenter (130 g/L initial xylose concentration). The $\mathrm{k}_{\mathrm{L}}$ a values were varied between 0 and $461 / \mathrm{h}$ in shake flasks, and it was concluded that increasing $\mathrm{k}_{\mathrm{L}}$ a resulted in decreasing xylitol and increasing cell mass production. Interestingly, the highest specific xylitol yield $(0.3 \mathrm{~g} / \mathrm{g})$ was achieved under anaerobic conditions $\left(01 / \mathrm{h} \mathrm{k}_{\mathrm{L}} \mathrm{a}\right)$. As a comparison, Winkelhasuen et al. [50] achieved a specific xylitol yield of $0.16 \mathrm{~g} / \mathrm{g}$ at $50 \mathrm{~g} / \mathrm{L}$ initial xylose concentration and $161 / \mathrm{h} \mathrm{k}_{\mathrm{L}} \mathrm{a}$ after $96 \mathrm{~h}$, which is lower than that of obtained in our study $(0.43 \mathrm{~g} / \mathrm{g})$ at an initial xylose concentration of $55 \mathrm{~g} / \mathrm{L}$ and $\mathrm{k}_{\mathrm{L}}$ a of $15 \mathrm{1} / \mathrm{h}\left(3.1 \mathrm{mmol} \mathrm{O}_{2} /(\mathrm{L} \times \mathrm{h}) \mathrm{OTR}\right)$ after $72 \mathrm{~h}$. The lower initial cell concentration $(1.3 \mathrm{~g} / \mathrm{L})$ applied by Winkelhasuen et al. [50] compared to that of used in our study $(5 \mathrm{~g} / \mathrm{L})$ could be one of the reasons for that. However, it is clear that xylitol producing capability can significantly differ with the subspecies of Candida boidinii also. Subspecies isolated from different environmental conditions might have XR and $\mathrm{XDH}$ enzymes with different characteristics, and different metabolic pathways for co-factors regeneration might have been activated in them, resulting in variable capability in xylitol fermentation under certain fermentation conditions. During the fermentations in a bioreactor using $130 \mathrm{~g} / \mathrm{L}$ initial xylose and $5 \mathrm{~g} / \mathrm{L}$ initial cell concentrations, Winkelhasuen et al. [50] achieved the highest specific xylitol yield (around $0.45 \mathrm{~g} / \mathrm{g}$ ) and xylitol volumetric productivity (around $0.26 \mathrm{~g} /(\mathrm{L} \times \mathrm{h})$ ) at $\mathrm{k}_{\mathrm{L}}$ a of $471 / \mathrm{h}$. It seemed that the increase in xylose and aeration together caused an increase in xylitol yield and productivity, however the increased initial cell mass could also have a positive effect on that. In our study, it was concluded that both initial xylose concentration and OTR had significant effects on the maximum xylitol yield and xylitol yield achieved after one day. However the interaction between xylose concentration and OTR had no significant effect within the investigated experimental range. It is worth it to note that the extent of their effects and their significant terms were different when the achievable maximum xylitol yield and the xylitol yield after a certain fermentation time (e.g., one day) was examined. In contrast, when the maximum xylitol volumetric productivity was evaluated, a clear interaction between OTR and initial xylose concentration was observed.

Xylitol fermentation on lignocellulosic hydrolysates by using Candida boidinii was previously tested by other studies. Santana et al. [51] investigated Candida boidinii XM02G (4 g/L initial cell mass) on cocoa pod husk hemicellulose hydrolysate detoxified by activated carbon, and a specific xylitol yield of $0.52 \mathrm{~g} / \mathrm{g}$ was achieved after $372 \mathrm{~h}$ of fermentation. Fehér et al. [39] published a xylitol yield of 53\% of theoretical and a xylitol volumetric productivity of $0.14 \mathrm{~g} /(\mathrm{L} \times \mathrm{h})$ reached after $72 \mathrm{~h}$ of fermentation by using C. boidinii NCAIM Y.01308 (5 g/L initial cell mass) on corn fibre hydrolysate detoxified by activated carbon. Lopez-Linares et al. [52] investigated the xylitol production of $C$. boidinii NCAIM Y.01308. (5 g/L initial mass) on exhausted olive pomace hydrolysate detoxified by ion-exchange resin and achieved $0.43 \mathrm{~g} / \mathrm{g}$ specific xylitol yield and $0.07 \mathrm{~g} /(\mathrm{L} \times \mathrm{h})$ volumetric productivity after $96 \mathrm{~h}$. In this study, the xylitol yield, the specific xylitol yield, and the volumetric productivity were $60 \%, 0.72 \mathrm{~g} / \mathrm{g}$, and $0.58 \mathrm{~g} /(\mathrm{L} \times \mathrm{h})$, respectively, on WB1/S after $24 \mathrm{~h}$. Those results exceeded the ones mentioned before. It is also important to note that in the case of WB1/S, no detoxification step was required prior to the fermentation. In our previous study, xylitol fermentation was performed by using Ogataea zsoltii NCAIM Y.01540 on xylose-rich wheat bran hydrolysate [17]. Comparing the maximum xylitol yields and volumetric productivities achieved under the same conditions by using 
O. zsoltii NCAIM Y.01540 (56\% and $0.24 \mathrm{~g} /(\mathrm{L} \times \mathrm{h}))$ and C. boidinii NCAIM Y.01308 (60\% and $0.58 \mathrm{~g} /(\mathrm{L} \times \mathrm{h}))$, xylitol production of C. boidinii NCAIM Y.01308 was found to be more advantageous. Based on these results, this study confirms that the xylose-rich hydrolysate of wheat bran is a suitable medium for xylitol fermentation without detoxification.

Mayerhoff et al. [53] investigated different yeast strains to ferment xylitol on sulfuric acid treated rice straw hydrolysate. In their work, the initial xylose concentration was $53.9 \mathrm{~g} / \mathrm{L}$ and $50 \mathrm{~mL}$ medium was used in $125 \mathrm{~mL}$-flasks at $200 \mathrm{rpm}$ shaking. High specific xylitol yields $(>0.6 \mathrm{~g} / \mathrm{g}$ ) were achieved after $75 \mathrm{~h}$ by several Candida strains such as C. guilliermondii FTI-20037, C. mogii NRRL Y-17032, C. parapsilosis IZ-1710, and C. veronae IZ-945. However, it was only $0.17 \mathrm{~g} / \mathrm{g}$ by using C. boidinii NRRL Y-17213. Compared to that, a higher specific xylitol yield was achieved by C. boidinii NCAIM Y.01308 in our study $(0.26 \mathrm{~g} / \mathrm{g}$ after $72 \mathrm{~h})$. Nitrogen source in the fermentation media is also an important factor influencing the xylitol production. Since rice straw hydrolysates contained very low amount of proteins, supplementation by ammonium-sulphate and peptone was tested in this study. Generally, organic nitrogen sources (e.g., yeast extract and urea) result in higher xylitol yield compared to the inorganic ones [54]. In accord with that, higher maximum xylitol yield was achieved on peptone-supplemented GRS/S (25\%) compared to GRS/S (20\%). Silvia and Roberto [55] also investigated the effect of the nutrient supplementation ( $2 \mathrm{~g} / \mathrm{L}$ $\left(\mathrm{NH}_{4}\right)_{2} \mathrm{SO}_{4}, 0.1 \mathrm{~g} / \mathrm{L} \mathrm{CaCl}_{2}{ }^{*} 2 \mathrm{H}_{2} \mathrm{O}$ and $10 \mathrm{~g} / \mathrm{L}$ rice bran extract) of rice straw hydrolysate in order to improve the xylitol production of $C$. guilliermondii FTI 20037. They found that the nitrogen supplementation had no effect on the specific xylitol yield $(0.36-0.37 \mathrm{~g} / \mathrm{g})$ achieved. In this study, a similar result was obtained, supplementation of GRS/S with peptone did not improve the specific xylitol yield ( $0.35 \mathrm{~g} / \mathrm{g}$ after $24 \mathrm{~h}$ ); however it increased the maximum xylitol yield from $20 \%$ to $25 \%$ of theoretical. Zeid et al. [56] investigated the effects of activated carbon treatment on xylitol production by C. tropicalis and C. guilliermondii using rice straw hydrolysate. After the activated carbon treatment, specific xylitol yields were increased from $0.25 \mathrm{~g} / \mathrm{g}$ and $0.47 \mathrm{~g} / \mathrm{g}$ to $0.61 \mathrm{~g} / \mathrm{g}$ and $0.69 \mathrm{~g} / \mathrm{g}$ in the cases of C. tropicalis and C. guilliermondii, respectively. Similarly, as a result of the activated carbon treatment of GRS/S, the maximum xylitol yield was increased from $25 \%$ to $30 \%$ in this study. Lopez Linares et al. [52] published a specific xylitol yield of $0.36 \mathrm{~g} / \mathrm{g}$ achieved on exhausted olive pomace hydrolysate treated by activated carbon after $72 \mathrm{~h}$ of fermentation by C. boidinii NCAIM Y.01308 (5 g/L initial cell mass, $50 \mathrm{~mL}$ medium in $100 \mathrm{~mL}$-flask, $150 \mathrm{rpm}$ shaking). That is slightly lower than that obtained in our study $(0.38 \mathrm{~g} / \mathrm{g})$ using peptone-supplemented GRS/S treated by activated carbon and the same yeast strain. One of the reasons for the low xylitol yields obtained in our study on rice straw hydrolysates is probably the presence of considerable amount of glucose (glucose/xylose ratio of 0.29 in GRS/S). A glucose/xylose ratio that is higher than 0.1 could negatively affect xylitol fermentation [52]. Moreover, the activated carbon treatment was not effective in removing the organic acids from GRS/S, which could also contribute to the insufficient bioconversion of xylose into xylitol. Bio-purification processes selectively removing organic acids and glucose from lignocellulosic hydrolysates $[57,58]$ or appropriate genetic modifications of the xylose-fermenting microorganisms $[59,60]$ are promising ways to overcome these kinds of obstacles.

\section{Conclusions}

Xylitol fermentation by C. boidinii NCAIM Y.01308 was optimised by investigating the effects of oxygen transfer rate and initial xylose concentration applied. The fitted models of maximum xylitol yield, maximum xylitol volumetric productivity, and xylitol yield after $24 \mathrm{~h}$ were verified and they were successfully used to predict xylitol production on wheat bran hydrolysate. Wheat bran hydrolysate was found to be an outstanding substrate for C. boidinii NCAIM Y.01308 to produce xylitol. Meanwhile, xylitol fermentation on rice straw hydrolysates by C. boidinii NCAIM Y.01308 requires further investigations to be improved. 
Supplementary Materials: The following are available online at https:/ /www.mdpi.com/2073-439 5/11/1/79/s1. Figure S1: Fermentation profiles obtained during the designed experiments of xylitol production on semi-defined medium by Candida boidinii NCAIM Y.01308. Figure S2: Thin-layer chromatography analysis of rice straw hydrolysates. STD: standard (X1: xylose, X2: xylobiose, X3: xylotriose, X4: xylotetraose, X5: xylopentaose, and X6: xylohexaose).

Author Contributions: S.B. conducted experiments, analyzed the data and wrote the manuscript. A.F. conducted experiments. C.F. and K.J. conceived and designed the research, were responsible for funding acquisition and corrected the manuscript. P.K. revised the manuscript. All authors have read and agreed to the published version of the manuscript.

Funding: The authors gratefully acknowledge the projects of TNN_16-123305 of the National Research, Development and Innovation Fund of Hungary, the project of VEKOP-2.3.2-16-2017-00013 supported by the European Union, the State of Hungary and the European Regional Development Fund for their financial support. This article is based on work from COST Action (CA18229, Yeast4Bio), supported by COST (European Cooperation in Science and Technology, www.cost.eu). The research was financed by the Higher Education Institutional Excellence Programme (NKFIH1150-6/2019) of the Ministry of Innovation and Technology of Hungary, within the framework of the Biotechnology thematic programme of the University of Debrecen.

Institutional Review Board Statement: Not applicable.

Informed Consent Statement: Not applicable.

Data Availability Statement: The data presented in this study are available on request from the corresponding author. The data are not publicly available due to privacy restrictions.

Acknowledgments: The authors are grateful to Gyermelyi Ltd. (Gyermely, Hungary), Suranaree University of Technology (Thailand), and National Collection of Agricultural and Industrial Microorganisms (Budapest, Hungary) for kindly providing research material; to Kinga Kóder for technical support and to Julie Johnson for linguistics editing.

Conflicts of Interest: The authors declare no conflict of interests.

\section{References}

1. Ubando, A.T.; Felix, C.B.; Chen, W.H. Biorefineries in circular bioeconomy: A comprehensive review. Bioresour. Technol. 2020, 299, 122585. [CrossRef] [PubMed]

2. Fehér, C.; Barta, Z.; Réczey, K. Process considerations of a biorefinery producing value-added products from corn fibre. Period. Polytech. Chem. Eng. 2012, 56, 9-19. [CrossRef]

3. Dahmen, N.; Lewandowski, I.; Zibek, S.; Weidtmann, A. Integrated lignocellulosic value chains in a growing bioeconomy: Status quo and perspectives. GCB Bioenergy 2019, 11, 107-117. [CrossRef]

4. Piotrowski, S.; Essel, R.; Carus, M.; Dammer, L.; Engel, L. Nachhaltig nutzbare Potenziale für Biokraftstoffe in Nutzungskonkurrenz zur Lebens-und Futtermittelproduktion, Bioenergie sowie zur stofflichen Nutzung in Deutschland, Europa und der Welt. Eur. Welt Nova-Institut 2015, 22501112, 1-252.

5. Isikgor, F.H.; Becer, C.R. Lignocellulosic biomass: A sustainable platform for the production of bio-based chemicals and polymers. Polym. Chem. 2015, 6, 4497-4559. [CrossRef]

6. Shiferaw, B.; Smale, M.; Braun, H.J.; Duveiller, E.; Reynolds, M.; Muricho, G. Crops that feed the world 10. Past successes and future challenges to the role played by wheat in global food security. Food Secur. 2013, 5, 291-317. [CrossRef]

7. Alexandri, M.; López-Gómez, J.P.; Olszewska-Widdrat, A.; Venus, J. Valorising agro-industrial wastes within the circular bioeconomy concept: The case of defatted rice bran with emphasis on bioconversion strategies. Fermentation $2020,6,42$. [CrossRef]

8. FAO. Cereal Supply and Demand Brief. Available online: http://www.fao.org/worldfoodsituation/csdb/en/ (accessed on 27 November 2020).

9. Bandumula, N. Rice Production in Asia: Key to Global Food Security. Proc. Natl. Acad. Sci. India Sect. B Biol. Sci. 2018, 88, 1323-1328. [CrossRef]

10. Sharma, I.; Tyagi, B.S.; Singh, G.; Venkatesh, K.; Gupta, O.P. Enhancing wheat production-A global perspective. Indian J. Agric. Sci. 2015, 85, 3-13.

11. Muthayya, S.; Sugimoto, J.D.; Montgomery, S.; Maberly, G.F. An overview of global rice production, supply, trade, and consumption. Ann. N. Y. Acad. Sci. 2014, 1324, 7-14. [CrossRef]

12. Prückler, M.; Siebenhandl-Ehn, S.; Apprich, S.; Höltinger, S.; Haas, C.; Schmid, E.; Kneifel, W. Wheat bran-based biorefinery 1: Composition of wheat bran and strategies of functionalization. LWT Food Sci. Technol. 2014, 56, 211-221. [CrossRef]

13. Kim, S.; Dale, B.E. Global potential bioethanol production from wasted crops and crop residues. Biomass Bioenergy 2004, 26, 361-375. [CrossRef] 
14. Balan, V.; Da Costa Sousa, L.; Chundawat, S.P.S.; Vismeh, R.; Jones, A.D.; Dale, B.E. Mushroom spent straw: A potential substrate for an ethanol-based biorefinery. J. Ind. Microbiol. Biotechnol. 2008, 35, 293-301. [CrossRef] [PubMed]

15. Koegelenberg, D.; Chimphango, A.F.A. Effects of wheat-bran arabinoxylan as partial flour replacer on bread properties. Food Chem. 2017, 221, 1606-1613. [CrossRef] [PubMed]

16. Kumar, A.; Gautam, A.; Dutt, D. Biotechnological Transformation of Lignocellulosic Biomass in to Industrial Products: An Overview. Adv. Biosci. Biotechnol. 2016, 7, 149-168. [CrossRef]

17. Bedő, S.; Antal, B.; Rozbach, M.; Fehér, A.; Fehér, C. Optimised fractionation of wheat bran for arabinose biopurification and xylitol fermentation by Ogataea zsoltii within a biorefinery process. Ind. Crops Prod. 2019, 139, 111504. [CrossRef]

18. Liaw, W.-C.; Chen, C.-S.; Chang, W.-S.; Chen, K.-P. Xylitol Production from Rice Straw Hemicellulose Hydrolyzate by Polyacrylic Hydrogel Thin Films with Immobilized Candida subtropicalis WF79. J. Biosci. Bioeng. 2008, 105, 97-105. [CrossRef]

19. Ylikahri, R. Metabolic and Nutritional Aspects of Xylitol. In Advances in Food Research; Chichester, C.O., Ed.; Academic Press: Cambridge, MA, USA, 1979; Volume 25, pp. 159-180.

20. Mussatto, S.I. Application of Xylitol in Food Formulations and Benefits for Health. In D-Xylitol; Springer: Berlin/Heidelberg, Germany, 2012; pp. 309-323.

21. Ravichandran, K.; Jain, J.; Sadhu, B.J.; Gunasekaran, S.; Poojitha, M.C.; Majumder, P.; Isaac, N. The efficacy of xylitol based oral hygiene products on salivary parameters-An invivo study. Int. J. Res. Pharm. Sci. 2020, 11, 953-959. [CrossRef]

22. Delgado Arcaño, Y.; Valmaña García, O.D.; Mandelli, D.; Carvalho, W.A.; Magalhães Pontes, L.A. Xylitol: A review on the progress and challenges of its production by chemical route. Catal. Today 2018, 344, 2-14. [CrossRef]

23. Mikkola, J.P.; Sjöholm, R.; Salmi, T.; Mäki-Arvela, P. Xylose hydrogenation: Kinetic and NMR studies of the reaction mechanisms. Catal. Today 1999, 48, 73-81. [CrossRef]

24. Yadav, M.; Mishra, D.K.; Hwang, J.S. Catalytic hydrogenation of xylose to xylitol using ruthenium catalyst on $\mathrm{NiO}_{\text {modified }} \mathrm{TiO} 2$ support. Appl. Catal. A Gen. 2012, 425-426, 110-116. [CrossRef]

25. Tran, L.H.; Yogo, M.; Ojima, H.; Idota, O.; Kawai, K.; Suzuki, T.; Takamizawa, K. The production of xylitol by enzymatic hydrolysis of agricultural wastes. Biotechnol. Bioprocess Eng. 2004, 9, 223-228. [CrossRef]

26. Espinoza-Acosta, J.L. Biotechnological Production of Xylitol from Agricultural Waste. Biotecnia 2020, XXII, 126-134.

27. Winkelhausen, E.; Pittman, P.; Kuzmanova, S.; Jeffries, T.W. Xylitol formation by Candida boidinii in oxygen limited chemostat culture. Biotechnol. Lett. 1996, 18, 753-758. [CrossRef]

28. Mussatto, S.I.; Roberto, I.C. Xylitol production from high xylose concentration: Evaluation of the fermentation in bioreactor under different stirring rates. J. Appl. Microbiol. 2003, 95, 331-337. [CrossRef]

29. Tamburini, E.; Costa, S.; Marchetti, M.G.; Pedrini, P. Optimized production of xylitol from xylose using a hyper-acidophilic Candida tropicalis. Biomolecules 2015, 5, 1979-1989. [CrossRef]

30. Nolleau, V.; Preziosi-Belloy, L.; Delgenes, J.P.; Navarro, J.M. Xylitol production from xylose by two yeast strains: Sugar tolerance. Curr. Microbiol. 1993, 27, 191-197. [CrossRef]

31. Felipe Hernández-Pérez, A.; de Arruda, P.V.; Sene, L.; da Silva, S.S.; Kumar Chandel, A.; de Almeida Felipe, M. das G. Xylitol bioproduction: State-of-the-art, industrial paradigm shift, and opportunities for integrated biorefineries. Crit. Rev. Biotechnol. 2019, 39, 924-943. [CrossRef]

32. Sluiter, A.; Hames, B.; Ruiz, R.; Scarlata, C.; Sluiter, J.; Templeton, D. Determination of Sugars, Byproducts, and Degradation Products in Liquid Fraction Process. Natl. Renew. Energy Lab. 2008, NREL/TP-510-42623, 1-11.

33. Hames, B.; Scarlata, C.; Sluiter, A. Determination of protein content in biomass. Natl. Renew. Energy Lab. 2008, NREL/TP-510-42625, $1-5$.

34. Sluiter, A.; Hames, B.; Ruiz, R.; Scarlata, C.; Sluiter, J.; Templeton, D. Determination of ash in biomass. Natl. Renew. Energy Lab. 2008, NREL/TP-510-42622, 1-5.

35. Jampatesh, S.; Sawisit, A.; Wong, N.; Jantama, S.S.; Jantama, K. Evaluation of inhibitory effect and feasible utilization of dilute acid-pretreated rice straws on succinate production by metabolically engineered Escherichia coli AS1600a. Bioresour. Technol. 2019, 273, 93-102. [CrossRef] [PubMed]

36. Palmarola-Adrados, B.; Chotěborská, P.; Galbe, M.; Zacchi, G. Ethanol production from non-starch carbohydrates of wheat bran. Bioresour. Technol. 2005, 96, 843-850. [CrossRef] [PubMed]

37. Guo, X.; Cavka, A.; Jönsson, L.J.; Hong, F. Comparison of methods for detoxification of spruce hydrolysate for bacterial cellulose production. Microb. Cell Fact. 2013, 12, 93. [CrossRef] [PubMed]

38. Bradford, M.M. A rapid and sensitive method for the quantitation of microgram quantities of protein utilizing the principle of protein-dye binding. Anal. Biochem. 1976, 72, 248-254. [CrossRef]

39. Fehér, C.; Gazsó, Z.; Gál, B.; Kontra, A.; Barta, Z.; Réczey, K. Integrated Process of Arabinose Biopurification and Xylitol Fermentation Based on the Diverse Action of Candida boidinii. Chem. Biochem. Eng. Q. 2015, 29, 587-597. [CrossRef]

40. Ghio, S.; Ontañon, O.; Piccinni, F.E.; Marrero Díaz de Villegas, R.; Talia, P.; Grasso, D.H.; Campos, E. Paenibacillus sp. A59 GH10 and GH11 Extracellular Endoxylanases: Application in Biomass Bioconversion. Bioenergy Res. 2018, 11, 174-190. [CrossRef]

41. WISE, W.S. The measurement of the aeration of biological culture media. J. Gen. Microbiol. 1950, 4, 167-177.

42. Nishikawa, M.; Nakamura, M.; Yagi, H.; Hashimoto, K.; Nishikawa, M.; Yagi, H. Gas absorption in aerated mixing vessels. J. Chem. Eng. Jpn. 1981, 14, 219-226. [CrossRef] 
43. Wyman, C.E.; Yang, B. Combined Severity Factor for Predicting Sugar Recovery in Acid-Catalyzed Pretreatment Followed by Enzymatic Hydrolysis. In Hydrothermal Processing in Biorefineries: Production of Bioethanol and High Added-Value Compounds of Second and Third Generation Biomass; Ruiz, H.A., Hedegaard Thomsen, M., Trajano, H.L., Eds.; Springer: Cham, Switzerland, 2017; pp. 161-180. ISBN 978-3-319-56457-9.

44. Fehér, C.; Gazsó, Z.; Tatijarern, P.; Molnár, M.; Barta, Z.; Réczey, K. Investigation of selective arabinose release from corn fibre by acid hydrolysis under mild conditions. J. Chem. Technol. Biotechnol. 2015, 90, 896-906. [CrossRef]

45. Vandeska, E.; Amartey, S.; Kuzmanova, S.; Jeffries, T. Effects of environmental conditions on production of xylitol by Candida boidinii. World J. Microbiol. Biotechnol. 1995, 11, 213-218. [CrossRef] [PubMed]

46. Vongsuvanlert, V.; Tani, Y. Xylitol production by a methanol yeast, Candida boidinii (Kloeckera sp.) No. 2201. J. Ferment. Bioeng. 1989, 67, 35-39. [CrossRef]

47. Kim, J.H.; Han, K.C.; Koh, Y.H.; Ryu, Y.W.; Seo, J.H. Optimization of fed-batch fermentation for xylitol production by Candida tropicalis. J. Ind. Microbiol. Biotechnol. 2002, 29, 16-19. [CrossRef] [PubMed]

48. Aranda-Barradas, J.S.; Garibay-Orijel, C.; Badillo-Corona, J.A.; Salgado-Manjarrez, E. A stoichiometric analysis of biological xylitol production. Biochem. Eng. J. 2010, 50, 1-9. [CrossRef]

49. Granström, T.B.; Izumori, K.; Leisola, M. A rare sugar xylitol. Part I: The biochemistry and biosynthesis of xylitol. Appl. Microbiol. Biotechnol. 2007, 74, 277-281. [CrossRef]

50. Winkelhausen, E.; Amartey, S.A.; Kuzmanova, S. Xylitol production from D-xylose at different oxygen transfer coefficients in a batch bioreactor. Eng. Life Sci. 2004, 4, 150-154. [CrossRef]

51. Santana, N.B.; Teixeira Dias, J.C.; Rezende, R.P.; Franco, M.; Silva Oliveira, L.K.; Souza, L.O. Production of xylitol and biodetoxification of cocoa pod husk hemicellulose hydrolysate by Candida boidinii XM02G. PLoS ONE 2018, 13, e0195206. [CrossRef]

52. López-Linares, J.C.; Ruiz, E.; Romero, I.; Castro, E.; Manzanares, P. Xylitol production from exhausted olive pomace by Candida boidinii. Appl. Sci. 2020, 10, 6966.

53. Mayerhoff, Z.D.V.L.; Roberto, I.C.; Silva, S.S. Xylitol production from rice straw hemicellulose hydrolysate using different yeast strains. Biotechnol. Lett. 1997, 19, 407-409. [CrossRef]

54. Dasgupta, D.; Bandhu, S.; Adhikari, D.K.; Ghosh, D. Challenges and prospects of xylitol production with whole cell bio-catalysis: A review. Microbiol. Res. 2017, 197, 9-21. [CrossRef]

55. Silva, C.J.S.M.; Roberto, I.C. Optimization of xylitol production by Candida guilliermondii FTI 20037 using response surface methodology. Process Biochem. 2001, 36, 1119-1124. [CrossRef]

56. Zeid, A.A.A.; El-Fouly, M.Z.; El-Zawahry, Y.A.; El-Mongy, T.M.; El-Aziz, A.B.A. Bioconversion of rice straw xylose to xylitol by a local strain of Candida Tropicalis. J. Appl. Sci. Res. 2008, 4, 975-986.

57. Schneider, H. Selective removal of acetic acid from hardwood-spent sulfite liquor using a mutant yeast. Enzyme Microb. Technol. 1996, 19, 94-98. [CrossRef]

58. Fehér, A.; Fehér, C.; Rozbach, M.; Rácz, G.; Fekete, M.; Hegedús, L.; Barta, Z. Treatments of Lignocellulosic Hydrolysates and Continuous-Flow Hydrogenation of Xylose to Xylitol. Chem. Eng. Technol. 2018, 41, 496-503. [CrossRef]

59. Hua, Y.; Wang, J.; Zhu, Y.; Zhang, B.; Kong, X.; Li, W.; Wang, D.; Hong, J. Release of glucose repression on xylose utilization in Kluyveromyces marxianus to enhance glucose-xylose co-utilization and xylitol production from corncob hydrolysate. Microb. Cell Fact. 2019, 18, 24. [CrossRef] [PubMed]

60. Kogje, A.; Ghosalkar, A. Xylitol production by Saccharomyces cerevisiae overexpressing different xylose reductases using nondetoxified hemicellulosic hydrolysate of corncob. 3 Biotech 2016, 6, 127. [CrossRef] 